\title{
Harnessing the Demographic Dividend in Africa Through Lessons From East Asia's Experience
}

Ehizuelen Michael Mitchell Omoruyi, Center of Nigerian Studies under the Institute of African Studies, Zhejiang Normal University, China

\begin{abstract}
Notably, East Asian economies successfully capitalized on shifts in their age structures to gain a boost in economic productivity, a phenomenon known as the demographic dividend. Nowadays, despite the hitherto sluggish pace of Africa's transition, experts remain optimistic that similar transformation in Africa may lead to faster development in coming decades. The paper attempts to answer the following three questions: (1) Can natural resource development help African economies harness its demographic dividend? (2) As China 40-years-long demographic dividend draws to an end, China is actively trying to capture fresh economic opportunities in higher-value-added productive activity. Can Africa seize this opportunity provided by its own emerging demographic dividend era? (3) Can imitation game help African economies harness its demographic dividend? Arguably, for African economies to imitate the East Asian miracle and harness a maximum demographic dividend, they should adhere to these three mechanisms: labor supply, savings, and human capital.
\end{abstract}

\section{KEYWORDS}

Africa, China, Demographic Dividend, Development, East Asia Economies, Human Capital, Labor Supply, Savings

\section{INTRODUCTION}

Demographic factors have from time to time taken the center-stage in the debate of the sources of economic growth. In the 18th century, Robert Malthus (political economist of the 18th and 19th centuries) wrote "an easy on the principle of population" in which he argued in 1798 that the booming population would doom the world to famine and disaster (Malthus, 1798); he had no idea how wrong he would prove to be. Two centuries on, the world population of 250 million at the time he gave his apocalyptic view has now gone up to over seven billion, and projected to reach 9.8 billion in 2050 , and 11.2 billion in 2100 (UNDESA, 2017), despite wars, plague, famine, and epidemics. World food production has been keeping pace with population growth until recently. As such, his theory is wholly discredited; demographers and economists, continue to debate over the correlation between population growth and economic expansion; also, based on diverse arguments from economic demographers and 
development economists, they wonder if population growth encourages, discourages or is independent of economic expansion. ${ }^{1}$

Hence, development economists and economic demographers tend to affirm that economic growth in high-income economies is likely to be relatively low in coming years in part due to slow population growth in these economies (Baker et al.,2005), Linden sees population growth as a problematic phenomenon because more people inevitably use more of the finite resources available on earth (Linden, 2017). Coale and Hoover (1958) affirm that sustained high fertility and deteriorating mortality make governments and household burdened with high youth dependency rates, lowering tax revenues and household savings respectively.

Moving beyond the Malthusian arguments, experts have now turned the focus of analysis towards the impact and changes in age structure rather than simply focusing on the amount and rapidity of population growth (or decline) (Mason, 2005a; Birdsal et al., 2001; Sachs, 2002; Bloom and Canning, 1999; Bloom and Freeman, 1986; Bloom and Williamson, 1998). As a result, around the turn of the century age structure and the related theory of a "demographic dividend" received special attention thanks to the series of influential papers from experts (Bloom, Canning, and Sevilla, 2002). With this development, by 2007, the United Nations Commission on Population and Development has focused its fortieth session on the socio-economic implications of changing the age structure (United Nations, 2007).

Speaking of implications, the life cycle consumption model proposes that different age groups in a population have different economic implications. The young needs investment in health and education, adults supply labor, income and savings and at old ages, there is a need for retirement income and, again, a requirement to invest in health. As the relative size of each of these age groups changes in the population, similar is the respective impact of the economic behavior connected with the diverse ages. Because of the declining population growth and consequent changes in age structure, the proportion of the working-age population is increasing in most developing nations, thereby offering a window of opportunity for these nations; this is referred to as the 'demographic dividend'.

The demographic dividend is definable as the potential economic benefit offered by changes in the age structure of the population, during the demographic transition, when there is a surge in working-age population and an associated decline in the dependent age population. What needs to be emphasized here is that economic gains from demographic dividend are not certain, as the term might misleadingly imply. Economic returns are not solely a function of the demographic dividend. As such, for economic benefits to materialize there is a need for policies dealing with education, public health and those that promote labor market flexibility, and provide incentives for investment and savings. On the contrary, if suitable policies are not formulated, demographic dividend might be a cost, leading to unemployment and an unbearable strain on education, health and old age security.

Nowadays, Africa is also going through the demographic transition, with fertility rates finally showing a declining trend. It is now experiencing a once in a lifetime demographic dividend as the working-age population bulges and the dependency ratio declines. This is evidenced from the fact that Africa is home to over one billion people (up from just 477 million people in 1980) ${ }^{2}$; this is eyecatching (see table 1). Africa is expected to see an acceleration of annual population growth in the immediate future. For instance, it is expected that Africa population will reach 1.6 billion inhabitants in 2030 and 2.4 billion people in 2050, as fertility declines from an average of 4.7 children per woman in 2015 to 3.9 in 2030 and 3.1 in 2050 (United Nations 2013a, 2013b). Under-five mortality rates are projected to decline from the current level of 101 deaths per 1000 births to 44 by 2050 (United Nations, 2013a). The United Nations report added that with declining mortality and fertility, Africa's share of the working-age population will surge from about 54 percent in 2010 to peak at about 64 percent in 2090. Africa will account for nearly all the growth in the world's labor force by 2100 , its share of the global working-age population is thus projected to surge from 1.6 percent in 2010 to over 41 percent by 2100 (Drummond et al., 2014), which represent an opportunity to reap a demographic dividend. 
Table 1. Africa Expected Demographic Profiles, 2015-2050

\begin{tabular}{|l|l|l|}
\hline Indicator & $\mathbf{2 0 1 5}$ & $\mathbf{2 0 5 0}$ Expectations \\
\hline Total Populations & & \\
\hline Under-Five Mortality Rate & 101 & 44 \\
\hline Life Expectancy at Birth & 58.2 years & 68.9 years \\
\hline Aggregate Fertility Rate & 4.67 & 3.09 \\
\hline The Growth Rate of inhabitants & 2.46 percent & 1.74 percent \\
\hline The inhabitants 65plus & 3.5 percent & 5.9 percent \\
\hline Inhabitants 15-64 & 55.9 percent & 61.9 percent \\
\hline Inhabitants aged 0-14 & 40.6 percent & 32.2 percent \\
\hline Young people aged 10-15 & 22.1 percent & 19.6 percent \\
\hline Young people 10-24 & 363.1 Million (31.1 percent) & 679.9 Million (28.4 percent) \\
\hline Percentage of people living in urban regions & 40.4 & 55.9 \\
\hline
\end{tabular}

Source: United Nations (2013a); United Nations (2014)

The worldwide environmental change and deliberations about drivers of global migration lead to renewed interest in population growth and global demographic change. The idea of the demographic dividend was introduced to highlight the benefits of fertility decline, yet among African leaders, it is also often interpreted as describing the benefits of their youthful populations. Due to its controversial nature, the topic of population was not explicitly included in the Sustainable Development Goals. In this controversial discussion, the author decides to choose Africa for this study due to the importance of the continent population transition to international development generally. As such, this paper provides a systematic reexamination of how African economies can harness its demographic dividend that is being offered to the continent and what it holds for Africa's future.

It is worth noting that between 1970 and 2020, the fertility rate declined in every nation in the world. Fertility tended to decrease more in nations with high initial fertility, another facet of demographic convergence. Among geographic regions, Africa and Europe are currently homes to the highest (4.3) and lowest (1.6) fertility rates, respectively (Bloom, 2020). Therefore, since the continent has one of the highest fertility rates in the world, the very young age structure of its population can either exacerbate poverty or enhance prosperity. In fact, despite the continent's efforts in decreasing poverty, the total number of people living in poverty has grown. Because fertility is higher among the poor, poverty and inequality across generations can worsen.

The paper further elucidates that for African nations to harness its demographic dividend, African nations must apply the imitation game by imitating the East Asian economies who took advantage of their demographic window of opportunity to drive macroeconomic growth and poverty reduction. In addition, it will be important for African economies to accelerate their demographic transition while making efforts to adhere to these three mechanisms: labor supply, savings, and human capital to boost inclusive growth and poverty reduction. The implication is that for economic benefits to materialize, it will require strong complementarities among these three mechanisms: labor supply, savings, and human capital. Also, it will be critical to ensure that solid institutional settings and the right supportive policies, including those fostering human capital accumulation, savings, and job creations are in place to translate this demographic opportunity into concrete economic growth and dividend.

Academically, the significance of this paper is to challenge development policymakers and their approach in researching Africa, China and East Asian economies demographic transition and their growing interrelations and enable researchers and non-researchers understand the various possible ways Africa can harness its demographic dividend. 
The paper divides into five parts. The first part introduces the topic; the second part looks at why is the demographic dividend a vital Idea? The third part looks at three possible ways Africa can harness its demographic dividend. The fourth part examines the key mechanisms that can influence the ability to capitalize on the demographic dividend in Africa. The fifth part deals with the conclusion of the paper and offer policy implications that emerge from it. The paper draws from various data collected from diverse sources, including government statistics, few interviews, second-hand academic literature, local and international news media, official government reports, and diplomatic speeches to understand the context of how Africa can harness its demographic dividend.

\section{WHY IS THE CONCEPT OF DEMOGRAPHIC DIVIDEND IMPERATIVE?}

Demographic dividend is a phenomenon that has a limited period, because as the large active or adult population will move to the oldest segment, there will be less cohort that were born during the period of the declining fertility, and concern will relate to taking care of the elderly (Ross, 2004). Some contributions indicate that demographic dividend needs to be accompanied by good policy choices so that economies can take advantage from it rather than being subject to economic and social threats such as unemployment. Bloom et al (2002) indicates that to translate the demographic into a gift for any economy, there should be a prioritization of some variables such as health, education, job creation and family planning. This depends only on the institutional environment and the established policies. With that said, there are various reasons why the champions of the demographic dividend concept think that the concept has turn out to be a vital hypothesis for economic advancement.

The first reason is because the champions of the concept think that the dividend makes it possible to eschew the Malthusian "obsession" with speedy population growth, a viewpoint that is gradually out of favor among economic demographers, development economists, policymakers, and the public. Undeniably, changes in fertility rates add to changes in age structure as do changes in mortality rates and age-specific migration. In order words, the Malthusian viewpoint has the merit of interpreting all three basic population procedures and exploring their net effect on poverty and social well-being (Malthus, 1798). Yet, its gloomy and under-qualified forecasts about the dire consequences of speedy population growth overstated the evidence and downplayed the significance of social policy and context.

Contrary to the Malthusian notion, the demographic dividend portrays a more optimistic picture of the influence of population change on welfare. The common debate is that a window of opportunity opens during the demographic transition when the number of the working-age populace is relatively plentiful compared with the people less likely to be economically active. Hence, development economists and economic demographers tend to emphasize the ways in which changing population age structure can promote aggregate savings rates (Williamson and Higgins 2001; Uddin et al., 2016), inevitable consequences of economic growth (Bloom and Canning, 2001; Mason, 2001; Ogunjimi and Dauda, 2018; United Nations, 2017; Bloom, 2020), and surge per capita income (Bloom and Williamson, 1998; Sánchez-Romero et al., 2017). On the contrary, other scholars think that education rather age structure brings demographic dividend (Lutz et al., 2019). Also, the dividend debate and its temporary window of opportunity move away from linear viewpoints on development, suggesting in its place, a more contingent and opportunistic standpoint.

The second reason is that the interest in the demographic dividend is its intuitive appeal. The notion of dependency generally matches popular intuition about the normative unfolding of the life course, from a phase of socialization and human capital formation to the adult age of production and to older ages of reduced economic activity. Dependency also builds on well-accepted anticipations of resource transfers across generations, and the same anticipations have been stated in theories of wealth flows (Caldwell, 2006) and models of national transfer accounts (Lee and Mason, 2006).

The third reason is that contrary to grand theories of development that are spatially and temporarily invariant (Rostow 1960), the demographic dividend suggests a nuanced, spatially grounded, and time- 
bound debate about how changes in a nation's age composition affect its development trajectory over both the short and longer terms. Economies have a window time during which the opportunity of a dividend materializes and can be seized.

Linked to the above three reasons, and based on the fourth reason, the dividend is more empirically testable than grand development theories, in part, because it is explicit about operative mechanisms, steps, and time lags. Hooks et al. (2016) claim that the examination on age structure and the dividend can assist to bypass the respective constraint of micro-level analysis of the effects of population on development. Hooks and his co-authors added that the present macro-level examination of aggregate population changes and their macroeconomic effects are beneficial in focusing attention on the national-level concerns that frequently animate worldwide policymakers. More so, thus far, these analyses are less rigorous from a statistical standpoint, and they obscure differences and inequality across sub-population within similar nations (Hooks et al., 2016).

As for Cassen (1994), micro-level investigations are in line with the individual and human rights rationale for population policy that emerge in the 1990s, and they can be more detailed and rigorous. Yet, as a disadvantage, their results do not directly inform national development arguments, and they must be carefully scaled up since micro-level relationships can frequently vary from those discovered at the aggregate level (Robinson, 1950).

Eloundou-Enyegue and Giroux's (2012) study showed that many siblings might impede their education, but a deterioration in national fertility happens predominantly among the higher socioeconomic group. Mason (2005a) and Bloom et al. (2010) study of age structure signify a middle ground where analyses can center on the economic behavior of smaller subunits within national populaces and comprehend the wide-ranging economic transformation in terms of both the behavior and the relative size of these subunits. Focusing on age structure improves understanding of likely demographic bonus by clarifying the steps that shift a nation from changes in age structure to socioeconomic advancements.

\subsection{Asia-Africa Development Divergence}

A comparison of the continent of Asia with Africa could be doubtful, as nations in these two continents are at such vastly different stages of development and population growth. As such, observers often claim that such a comparison is akin to comparing apples and oranges. This mixed picture is particularly striking if one compares the generally robust performance of East Asian economies with those in Africa, which has been the subject of much debate (The World Bank 2000, Morisset 2000, Ayittey 1998, Easterly and Levine 1997, Bates 1981). But, from the early 1970s to the late 1990s, East Asia's economic growth transfixed the world. Aggregate wealth rose, inequality shrank, and Asia's share of world trade and global influence steadily and rapidly grew. This "Asian Miracle" was led by Japan, with Taiwan, South Korea, Hong Kong, Singapore, Malaysia, Indonesia, Thailand, and China. The Asian Miracle is doubly remarkable when juxtaposed with the economies of Africa, whose abject poverty is among the most obdurate features of the world economy. At present, Asian region now sits at the global table as a player while African region sits in the back rows, an object of concern due to it continued poverty and the associated security concerns. Most Asian economies are now donor in what is called "triangular" (it used to be called "South-South") cooperation while the African region at least until recently, was a long-term aid addict.

The most reliable estimates of the world and regional gross domestic product for the period of 1820-1992 are those prepared by the economic historian Angus Maddison (1995) ${ }^{3}$ (see Table 2) where on the one hand, he classified nations into "developed"- comprises of Western Europe, its offshoots as well as Japan - and on the other hand, "developing"- comprises of most notably Africa, but also much of Asia and Latin America. According to his estimates, at the start of this period, Africa had one-third the income level of the richest region at that time, Western Europe. But by 1992, it had one-twentieth the income level of the richest region, Maddison's "Western Offshoots," which includes the United States, Canada, Australia, and New Zealand. Maddison estimates that Africa's per capita 
Table 2. Economic Growth by Region, 1820-1992

Percent (annual rates)

\begin{tabular}{|l|l|l|l|l|l|}
\hline Period & West Europe & Western Offshoots & Asia & Africa & World Total \\
\hline $\mathbf{1 8 2 0 - 1 8 6 9}$ & 1.0 & 1.4 & 0.1 & 0.1 & 0.6 \\
\hline $\mathbf{1 8 7 0 - 1 9 1 2}$ & 1.3 & 1.8 & 0.6 & 0.4 & 1.3 \\
\hline $\mathbf{1 9 1 3 - 1 9 4 9}$ & 0.9 & 1.6 & 0.1 & 1.0 & 0.9 \\
\hline $\mathbf{1 9 5 0 - 1 9 7 2}$ & 3.9 & 2.4 & 3.8 & 2.1 & 2.9 \\
\hline $\mathbf{1 9 7 3 - 1 9 9 2}$ & 1.8 & 1.4 & 3.2 & -0.1 & 1.2 \\
\hline
\end{tabular}

Source: Maddison (1995)

income in 1992 was approximately that of Western Europe in 1820 (in purchasing power parity 1990 dollars). While this is only a broad approximation, it does put into perspective the extent of Africa's economic plight. Table 1 summarizes the economic growth of selected regions over this period.

Growth is measured in GDP per capita, as measured in 1990 International Geary-Khamis dollars.

These figures reveal the striking divergence between Asia and Africa in the period 1950-1972, the period during which most of the European colonies in these two regions achieved independence. Asia experienced continued growth of 3.2 percent annually through the period 1973-1992, while Africa's economic growth turned negative. In the late 1950s and early 1960s, GDP per capita was roughly equal, but during the 1970s Asia's growth created a widening gap between the two regions. In the early 1980s Africa's GDP per capita reached a zenith from which it began to decline, while Asia's growth continued to accelerate. Clearly, while the Asian tigers were beginning to roar, those in Africa only got poorer.

By looking at the first half of the 20th century, it is worth noting that many parts of Asian continent suffered through extreme poverty and decimation, ${ }^{4}$ thanks in part to World War II, which itself precipitated wars in Japan and Korea, the Great Leap Forward in China, and the partition of India. But in the turn of the 21st century, powerhouses such as China and India had abandoned their communist and colonial governments, marshaled private funding, increased overseas direct investment, and positioned themselves as export economies. Places like Hong Kong, Singapore, and Taiwan also spurred Asia's wealth by reinventing themselves as the central - and indispensable - financial centers of Asian economy.

This development divergence in post-colonial fortunes is not just an Asian history. The 1950 African economy was awash in money from oil, gold, diamonds, and other natural resources that, combined with Africa's land wealth (Sub-Saharan Africa is larger than China, the United States, and India combined), should have fostered diverse and fruitful market. But colonialism and the slave trade had left the continent of Africa with little labor; between 1650 and 1850, Africa's population barely grew (Olamosu and Wynne, 2015). However, this is changing; over the last century Africa's population has grown at a rapid rate. In terms of comparing Africa's population trend with other regions, figure 1 display the evolution of population trends globally since 1950, with projections for 2100 . The graph shows that East Asia has traditionally been a densely populated region with abundant labor. Africa, in contrast, is rather labor scarce and land abundant. It is worth noting that without sufficient labor or capital, African national economies turned out to be monoculture (mineral or commodity) exporters, relying on outsiders for know-how, equipment, technology and consumer products. By the 1980s, only five African nations (Benin, Sierra Leone, Morocco, Senegal and Zimbabwe) had diversified export bases (Olamosu and Wynne, 2015). 
Figure 1. Populations Trend of the World's Continent from 1950 to 2100 (in millions)

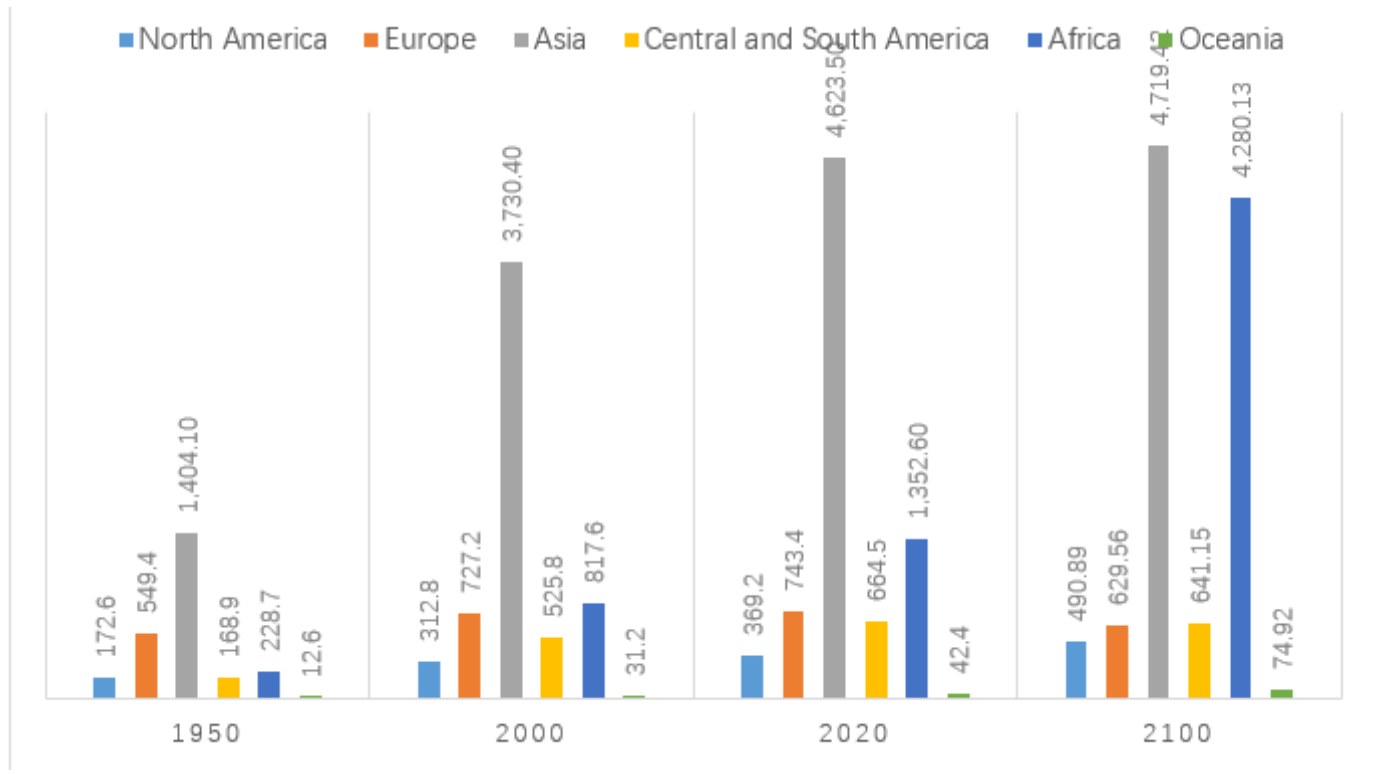

Source: Statista, 2020

Note: Population of the world's continents from 1950 to 2020 (in millions) Retrieved $16^{\text {th }}$, May 2021 from https://www.statista.com/statistics/997040/world-population-by-continent-1950-2020/

It is telling of Africa's deep resource wealth that it took over 35 years for average incomes in Asia to catch up. Some economists, such as Jeffrey Sachs, believe that resources are a curse: nations such as Cameroon, for instance, have experienced weaker growth than less resource-abundant nations (Sachs and Warner, 1995). Economists Elsa Artadi and Xavier Sala-i-Martin contend that Africa was also hurt by diminishing investment, education enrollment, and health (Artadi and Sala-i-Martin, 2003). Between 1975 and 2003, investment in the continent of Africa fell by 8.5 percent while investment in East Asia grew 30 percent. Artadi and Sala-i-Martin estimate that if Africa's school enrollment rates had matched the OECD's in the 40 years since 1975, its economy would have grown by 2.3 percent (instead of 0.9 percent). However, this was not the case in Asia since Asian economies used their resources with better institutions and policies to grow their economies. Therefore, African nations were hurt not by their richness in one resource, but by the absence of political and economic institutions prior to the discovery of that resources.

As such, without such political and economic institutions, which can turn a one-commodity boon into a diversified economy, Africa's resource well will eventually run dry. This elucidates the reason for the diverging trajectories of development between Asia and Africa. Notably, it is interesting to note that the set of factors for the trajectory development of Asian economies includes (i) sound macroeconomic policies tackling inflation that lead to macroeconomic stability (ii) economic freedom to peasants, and (iii) pro-poor public spending. All of them should be present as each factor is individually necessary but not sufficient to effect successful development. Altogether, the presence of these policies in Asian economies cases amount to a state-led agricultural development that later serves as a foundation for export-industrialization. Similarly, the absence of these policies in Africa case leads to no less than a developmental failure. Arguably, the presence and absence of such policies can be accounted for by the intention underlying policymaking on the part of the political elites of African nations. It is in this context we look at possible ways the continent of Africa can harness its demographic dividend. 


\section{THREE POSSIBLE WAYS AFRICA'S CAN HARNESS ITS DEMOGRAPHIC DIVIDEND}

\subsection{Leveraging Natural Resources}

Nations in Africa fall into three categories: oil-producing, non-oil resources-rich, and resource-poor nations. And the continent minerals account for an average of 70 percent of total Africa exports and almost 28 percent of gross domestic product (GDP) (ANRC, 2015). For some economies in Africa, natural resources provide almost all their fiscal revenue. The African Development Bank estimates that natural resources will contribute over US\$30 billion per annum in government revenue up to 2035 (AfDB, 2015). Revenues received from natural resources allow for increased public spending in areas directly related to human development, including health, education, and social protection but can also support employment, procurement, infrastructure spending, and social investment. All these offer additional opportunities that African governments can leverage to fast-track their national development goals.

As Africa continues its development through the 21st century, natural resources development will play a vital role. As such, the continent's famous resource-wealth is a somewhat helpful factor as FDI has grown in all three categories such as oil-producing, non-oil resources-rich, and resourcepoor nations, but at different rates (Cho and Tien, 2013). These FDI flows usually provide a boost to the economy through additional domestic investment. As a result, the nature of FDI is important because it will affect the likelihood of investments that will produce jobs: generating high-paying jobs for the youth bulge moving into working age is essential to capturing the economic payoffs.

The argument for developing natural resources is clear and simple. Nations with natural resources can earn significant economic rents, which their governments can invest or spend to improve public welfare and create intergenerational wealth. With proper management, resource revenue can enhance development that leads to sustainable economic growth. Nations seeking to use their fledgling energy sector to garner economic development would do well if these nations focus on human capital development to create forward and backward linkages that can achieve positive economic spillovers. As numerous African economies are expected to undergo the demographic transition by 2050, could natural resources development, productive investment, and the proper management of resource revenue help these African economies harness their demographic dividend? The answer is yes, but this is highly dependent on the timing of a nation's demographic transition, amount of recoverable resources, development profile for extracting and producing the resources, and economic growth policies for investing resources revenue.

Nigeria will be a good nation to use in this illustration. Between 2020 and 2050, Nigeria (due to population momentum, Nigeria is projected to overtake the United States to become the world's third-most-populous nation) Nigeria population is expected to grow to 239 million by 2025 and 440 million by 2050 (United Nations, 2012). Most of this growth will be people of working ages, between age 15 and 64. Therefore, the dependency ratio, or the number of children and elderly (under age 15 and over 65) divided by the number of working-age adults (between ages 15-64), will fall over this period from 88 dependents per 100 workers in 2010 to only 69 dependents per 100 workers by 2050 . The median age of the total population is also expected to surge from 17.9 to 21.4 over the 40 -year period from 2010 to 2050 (United Nations, 2012).

These trends are of significance because Nigeria is anticipated to make up 3 percent of the total world population and 14 percent of Africa's population by 2050 (United Nations, 2009). Therefore, Nigeria is poised to be a key player in the global system, and particularly important in the African region. Additionally, to its valuable human capital, Nigeria oil and gas resources present a potential development boost. Nigeria contains 37,062 billion barrels of proven oil reserves (WorldAtlas, 2018), and it is expected to surge to 40 billion barrels of proven oil reserves by $2020^{5}$ and 192 trillion cubic feet respectively ${ }^{6}$ and over 5 trillion cubic meters of natural gas reserves (CIA, 2017). Nigeria also aimed to increase its gas reserves to $210 \mathrm{Tcf}$ by 2025 and to $220 \mathrm{Tcf}$ by 2030 . According to the Nigerian 
National Petroleum Corporation (NNPC), Nigeria has a maximum crude oil production capacity of 2.5 million barrels per day (NNPC, 2018). It is already ranked among the top 6 oil producers globally, ranked as Africa's largest producer, and possesses the largest natural gas reserves in Africa. ${ }^{7}$

Nigeria holds great potential energy resources (renewable and non-renewable). For example, Nigeria produced over 34 billion cubic meters of gas in 2007, exporting 21 billion (Reed and Mberu, 2014), and has the 10th largest oil reserves in the world, generating 75 percent of government revenue (USAID, 2015). More so, over 90 percent of Nigeria's exports revenue and 35 percent of total GDP comes from the oil industry (Wapner, 2017). Yet, despite these tremendous resource advantages, the nation continues to lag on countless development indicators. Will Nigeria current and future population composition be a bonus or a burden? Primarily, Nigeria has not used the revenue from the natural resources properly to invest in its current future workforce, nor has the nation developed its oil and gas industries to produce long-term growth in both jobs and GDP, nor has it diversified its economy (World Bank/DFID, 2005).

Speaking of creating employment, the oil and gas industry divides broadly into three sectors: upstream, midstream, and downstream. The upstream sector centers on mining, exploration, production and exportation; the mid-stream is concerned with the refining of petroleum products for domestic purposes; the downstream sector involves the distribution, marketing and sales of petroleum products in the domestic market (Chidi et al., 2011). The major employers of labor in the downstream sector are indigenous businesspeople.

With that said, based on an interview with a Shell staff, ${ }^{8}$ Shell, the British/Dutch petroleum operator with exploration and production rights in Nigeria, will need a peak level of over 13,000 direct workers (during the construction phase) and a sustained workforce of over 3, 000 direct employment at crude production plateau; these workers are supposed to come from upstream sector. Notably, oil and gas activity in Nigeria has the potential to generate 200,000-350, 000 indirect and direct employment, although 70 percent of this employment will be short-term during the peak construction phase and will have to be transferred to other economic sectors or to neighboring nations to remain sustainable. ${ }^{9}$ Arguably, in the energy sector, having a technical qualification or certification and keeping skills up-to-date can be critical for maintaining competitiveness. Particularly, technological innovations in this sector require employers and workers within this sector to develop strategies to ensure that their skills remain current to retain comparative advantages. Nigeria, like most other resource African economies, does not have the highly skilled human capital to meaningfully participate in the energy sector because of low investment in education and human capital development programs.

Education is the most important factor in career progression because a large proportion of those with lower education levels have limited access to upskilling or reskilling opportunities. Continentwise, in order for African economies to formulate their own economic strategies that will assist the continent to attain structural transformation, African Union has to play an important role in advancing the implementation of Agenda 2063 and Sustainable Development Goals (SDGs), by creating suitable policies, knowledge exchange and financing mechanisms to address the inter-sectoral nature of the post-Agenda 2063 and post-2030 sustainable development agenda, plus the creation of the suitable business environment and investment in knowledge infrastructure. Among these policy ingredients, the creation of a skilled labor force, especially amongst the youth is imperative because the power of the youth drives structural transformation. This was a vital factor in the success of the East Asian economies and recently, the Chinese economy.

FDI itself often contributes to raising the skills level of the labor force, as foreign firms tend to invest more in training of their own workers and their suppliers, and skilled workers employed in overseas firms migrate to domestic firms. Government policy can often help to reinforce these trends through, for instance, including provisions for employment training of local workers, encouraging foreign firms to invest in broader training efforts that benefit the sector, and investing in education.

Speaking of education, the United Nations Educational, Scientific and Cultural Organization (UNESCO) recommended that the education sector should not be allocated anything lower than 26 
percent of a nation's national budget. ${ }^{10}$ UNESCO recommended the budgetary benchmark to enable nations to adequately cater for rising education demands and, in turn, help these economies harness their demographic dividend. However, in the case of Nigeria, the government allocated only 7.04 percent of the 8.6 trillion 2018 budget to education (Premium Times, 2018). Nigeria government needs to know that harnessing and seizing Nigeria's demographic dividend requires investing in education. This is because intellectual capital is like a crown jewel and has increasingly surfaced to become a leveraging mechanism, providing an important competitive edge.

Nigeria's youth are entering working age ill-prepared in terms of basic skills. UNESCO's Global Monitoring Report asserts that Nigeria "has some of the worst education indicator globally" (UNESCO, 2012). Population trends and dynamics can have an enormous effect on the prospects for poverty reduction and sustainable development if harness properly. As such, with the size of Nigeria's recoverable oil reserves, coupled with proper management of the oil revenues, good governance, longterm economic policies that support productive job, bolster per capita income that is combined with human capital development as well as attractive incentives could generate the linkages to accelerate economic growth and help Nigeria harness its demographic dividend later this century.

Meanwhile, all this must be done while struggling with the economic and political issues of the resource curse that Nigeria will inevitably encounter. If Nigeria can navigate those issues successfully, it could become the first Africa oil and gas-exporting nation to realize a natural resource blessing, and becoming not only an African, but a global champion and leader.

\subsection{Harnessing The Window of Opportunity in China-Africa Shifting Demographic}

The year 2021 marks the Communist Party of China (CPC) 100 years of existence. Its history in the past century has three phases - The 28 years of bellicosity and struggle to gain power; The 29 formative and consolidation years and; The 43 growth years. In the century, CPC has been in power for 72 unbroken years. After some testy 29 years when its major feat was giving the nation respite from wars and ensuring stability, the past 43 years have been those of growth and expansion in all directions.

Since 1978, CPC leadership of China turned a corner that has midwifed unprecedented growth and expansion in the economy, human capital, technology, global influence and diplomatic savvy to make China a standard for advancement globally. All these could not have been possible without the help of a strong Chinese demographic dividend.

As the nation's over four decade-long demographic dividend ends, the nation is facing a daunting challenge of a working-age population that has entered a seemingly terminal decline (Chan, 2015). As such, China is actively trying to capture fresh economic opportunities in high-valued-added productive activity in other nations. This brings the author to his fundamental question: Can Africa capture this opportunity offered by their own emerging demographic dividend period? Notably, Agenda 2063 is the shared vision for "an integrated, prosperous and peaceful Africa, driven by its own people and representing a dynamic force in the global arena (Africa Union, 2015). This vision for Africa places a big bet on the capability of African economies to accelerate economic growth by harnessing the continent's demographic dividend. Also, African leaders at the highest ministerial meeting declared 2017 as the year of "Harnessing the Demographic Dividend through Investment in Youth" (Africa Union, 2017).

Over the decade, it has become evident that a demographic dividend lens offers a strategic basis to attain sustainable development, inclusive growth, and to build "an integrated, prosperous and peaceful Africa, which is driven by its own citizen and representing a dynamic force in the international arena. However, the hopes that Africa's dramatic population bulge may create prosperity seem to have been overdone. Although economic demographers and development economists talk about a demographic dividend for Africa, however, what the continent has now is not a 'dividend' but a youth 'bulge'. Ssewamala (2015) affirms that the 'youth bulge' needs to gain skills that can be directed towards 


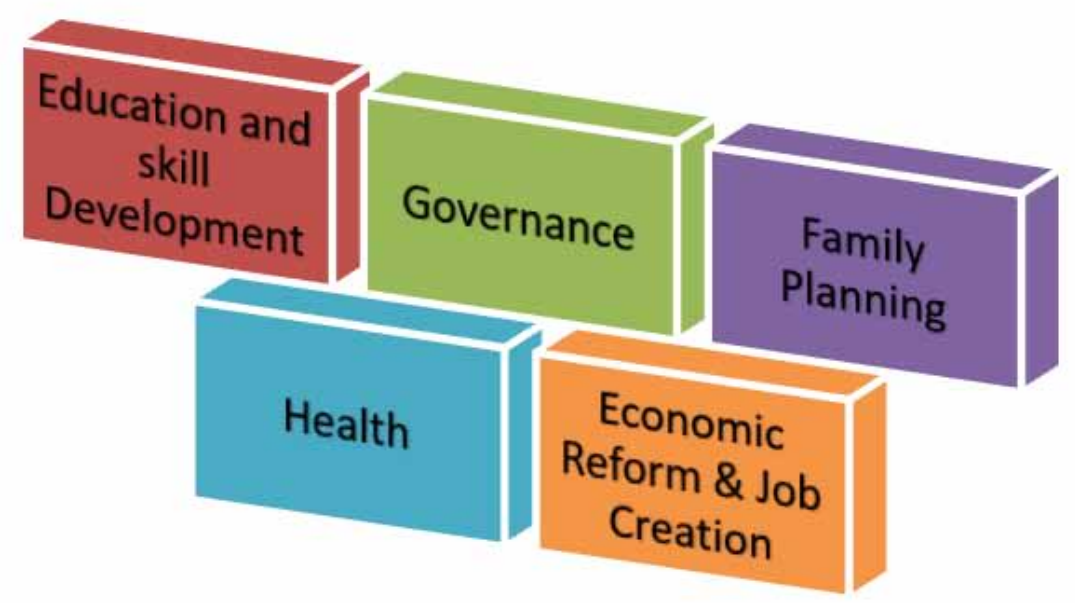

Source: Author's illustration

productive activities. As it stands now, it seems that Africa is moving at a pace much slower than its potential due to the untapped potential of its young population.

Before COVID-19, Africa GDP growth was projected to accelerate to 4 percent in 2019 and 4.1 percent in 2020 (AfDB, 2019). While higher than that of other developed, emerging, developing nations as well as world average GDP of 3.2 percent (IMF, 2019a), it remains insufficient to address the structural challenges of the persistent current and fiscal deficits and debt vulnerability. The challenge is therefore twofold: to raise the current growth path and to invest in skills that will help increase value addition and the efficiency of growth in creating jobs. What this means is that growth has not been in the areas that are labor-intensive. For instance, Africa spends about US $\$ 30$ billion importing processed foods every year and could create 5 million jobs just by transforming natural minerals by 5 percent (ECA, 2016).

There is need to develop the high workforce needed to compete in the global knowledge-based economy, especially now that China seeks to relocate its export-oriented low-wage light manufacturing factories to nowadays "poor and young" demographic dividend "frontier" nations (Johnston, 2018). Johnston added that during China's reform and opening up period, being home to youthful, poor, and mostly agrarian populace offered the nation similar extraordinary - and temporary-economic window of opportunity, which the nation took advantage of via successful surge agenda of "reform and opening up" in the nation's efforts to attain the "Four Modernizations" which help to strengthen the following sectors such as science and technology, industry, agriculture, and defense.

China's shifts from the demographic dividend to reform dividend by adhering to the five policy pillars in figure 2, arguably opened by far the greatest export-led Lewis model-style of industrialization and growth window ever seen in the history of humankind. Growth in China's workforce was a significant drive that assisted the nation spur economic transformation and opening, and was the main reason those coordinated policies which were in line with the five policy pillars yielded such a robust growth for China. As a lesson for African leaders nowadays, Chinese leadership did not fail to use their demographic dividend to bolster the nation's economy and create shared prosperity for the Chinese people. 


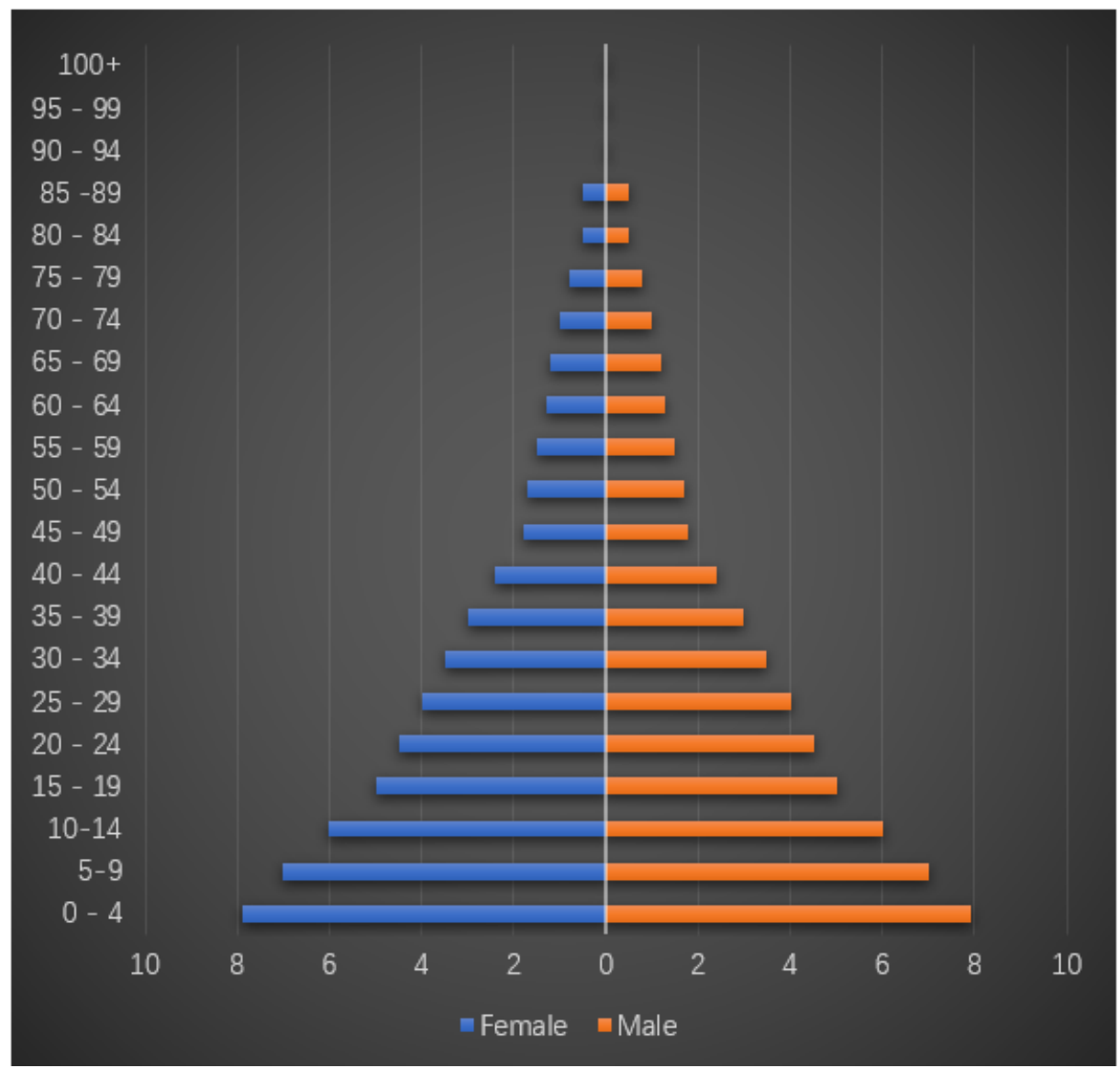

\section{Source: UNDESA, 2016}

With that said, today, China's four-decade long demographic dividend that is ending its timely for Africa. This is because it has been estimated that China's dropping support ratio alone will dampen growth by as much as 1.2 percent annually, against an earlier positive effective of 1.4 percent annually (UDESA, 2017). Bearing in mind, workforce share in China, however, is now falling, putting upward pressure on wages and downward pressure on total productivity. To retain the same level of output per capita, China must now produce more output per workers than during the period of demographic dividend boom. One of the ways China aims to achieve this is by shifting domestic low-cost laborintensive production overseas and moving into higher value-added industries and services.

Wages comparison between one of China's labor-intensive manufacturing hubs, Guangdong province, and those of an emerging industrial park in Ethiopia tells the narrative of why China-Africa shifting demographic is timely and why Africa is in focus for realizing the former objective. Johnston (2016) claims that the minimum wage in Guangdong is about US\$300; in Ethiopia's Hawassa Industrial Park, the average is about US\$50 monthly. Moreover, and in general, Africa sits on the edge of the potential of its own period of demographic dividend - like the demographic and development curve at which China sat over four decades ago. As the China-Africa economic relations took off in 2000, much of the trade and investment between the two sides reflected the fact that China was a labor-intensive 


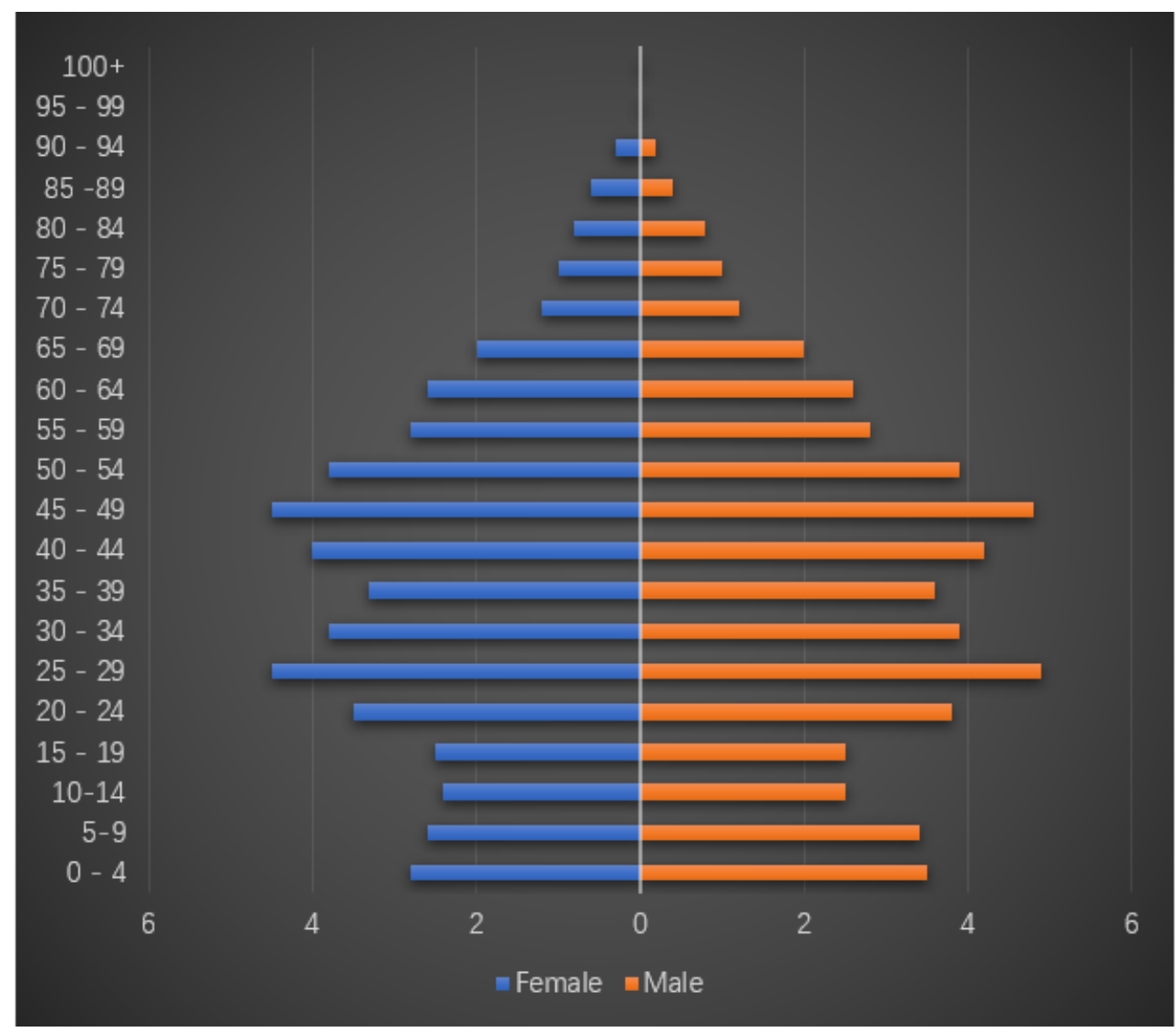

Source: UNDESA, 2016

nation trying to create as much employment as possible (especially in manufacturing), whereas Africa was resource-rich and relatively underpopulated. That dynamic is shifting speedily because of the shifting demographics in both places, which will establish a dissimilar basis for China-Africa economic engagement. Unarguably, the continent of Africa has an extraordinary young population, with almost half of its populace under the age of 20 (see figure 3 ).

Because of Africa remarkable young population, the age distribution follows a pyramid shape that is typical at an early phase of industrialization. Fertility remains high, as traditionally the situation in subsistence economies, but infant mortality has dropped because of modern medicine and the spread of better health and education services. As a result, there has been a spurt in the population as more children survive. There is a possibility of certainty that workforce will surge dramatically in the next two decades as those between 18 and 20 years old will join the workforce. Even if fertility is anticipated to decrease slowly - a trend already observable in some African economies - there is likely to be a significant expansion of the workforce for a long period. As for China, the nation's demographic is very dissimilar from the continent of Africa (see figure 4).

Notably, only nearly 20 percent of China populace is younger than 19 years old. The large cohort between the ages of 25 and 54 mirrors the speedy population expansion of the late 1960s and 1970s. This followed by the decrease in fertility that brought about partly from improved access to birth control, urbanization, and better education. China's family planning policy, which limited most 
Figure 5. Working-age Population in Africa and China

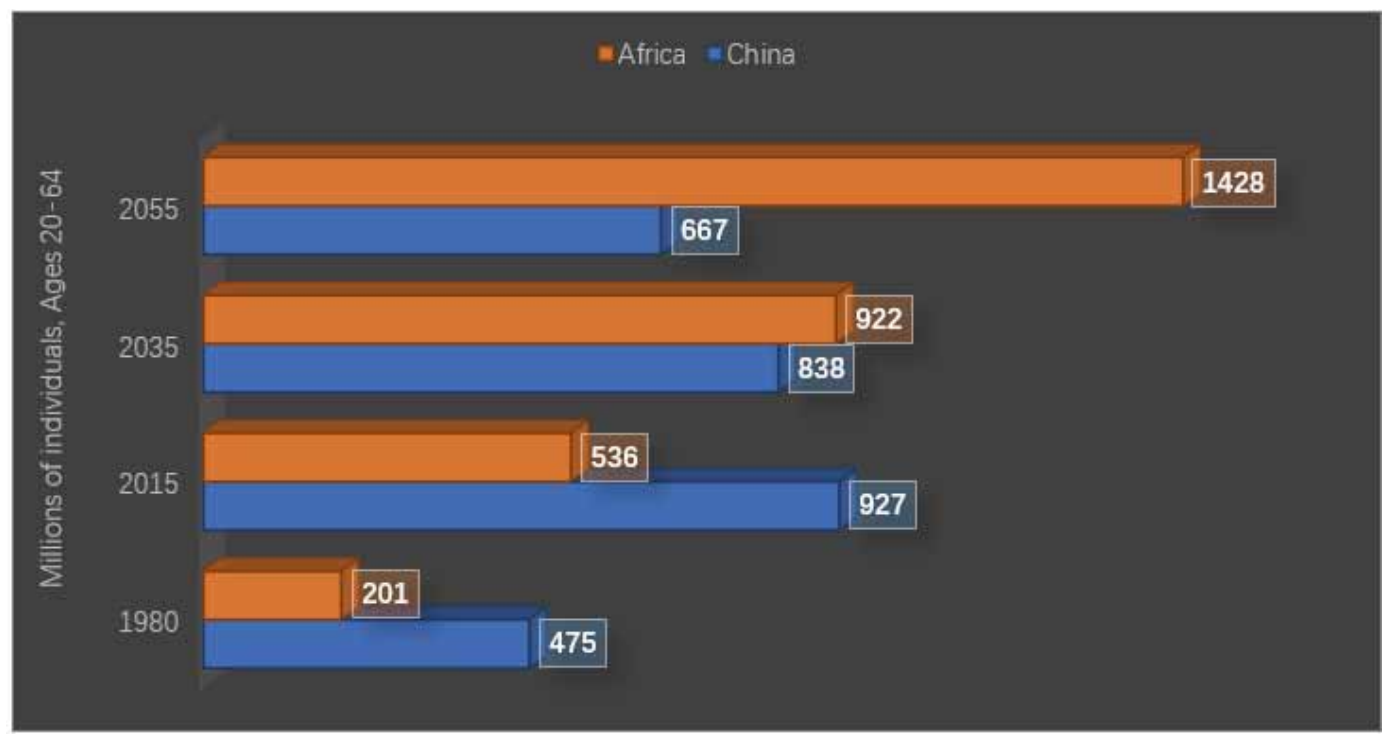

Source: UNDESA, 2016

urban families to one child, augmented the nation's demographic adjustment. China's population has augmented significantly in recent years, particularly its working-age populace. If working-age is to be defined as between 20 and 64 years, then China's population is approximately doubled between 1980 and 2015, from 475 million to 927 million (see figure 5).

Likewise, figure 5 shows the estimated working-age population of Africa in 2035 and 2055. Notably, China's working-age population has peaked and is presently starting to slowly decrease. According to the United Nation estimates, while China's working-age population will fall by 100 million, the continent of Africa demographic will shift in the other direction. Over the next decades, Africa will experience the type of explosive workforce expansion that China experience after 1980. Especially, the working-age population in Africa to soar from 536 million in 2015 to 922 million in 2035. Even though fertility drops, as it is estimated, there is a significant momentum for population growth. Nonetheless, based on the uncertainty that goes with the long-term forecast, the United Nations projection for 2055 displays Africa working-age population is soaring to 1.4 billion and China will drop to 667 million. At a minimum, it is obvious that we are shifting into an era in which China's workforce will shrink - albeit modestly - while Africa workforce surges dramatically. By 2050, of the 2.37 billion surges in population anticipated globally, Africa alone will contribute 54 percent. ${ }^{11}$

As the population in China and the developed world is ageing, they will seek locations to invest their savings, which they require to support themselves in old age. As for Africa, for the continent to keep up with its population growth, the continent needs to generate 20 million employment opportunities (Dollar, 2016). So, as Chinese policymakers seek to identify and capture fresh economic opportunities in advanced manufacturing and tertiary sectors in more advanced coastal provinces, while relocating less advanced industries to inland provinces and other locations outside China as a result of high wage issue in China (Yao and Wang, 2017), this provides a huge opportunity for African nations to generate some of the 20 million employment opportunities in their various nations by taking advantage of the cross-country differences in the timing of population ageing. African economies, of course, must do their part to actualize this result. 
Ethiopia, for example, a former war-torn and famine-plagued nation at the beginning of the 1990s but nowadays emerging as one of the fastest growing economies in Africa is making deliberate efforts to attract Chinese manufacturing by developing industrial zones with adequate, reliable infrastructure and improving the investment environment. The government has set its eyes on transforming the nation into a middle-income nation by 2025 , and into a leading manufacturing hub in Africa. To support this vision as well as develop more industrial zones, the nation received a US\$250 million World Bank loan to assist in developing the Bole Lemi Special Economic Zones (SEZs) outside Addis Ababa, as well as a new industrial center in Kilinto, 20 miles south of the capital. Over the last couple of years, Ethiopia has attracted over 15 major Chinese investment in sectors such as textile and electronics (Reuter, 2014).

One of the factors attracting firms to Ethiopia is low wages due to the nation's demographic advantage. Though the total number of firms investing is small, their cumulative economic impact appears to be significant. In Ethiopia, industry accounts for 14 percent of the nation's GDP, but it augmented to 21 percent between 2013 and 2014 (Dollar, 2016). Beginning from such a low base, even a modest amount of activity can have a large effect. Notably, the Ethiopian Ministry of Finance and Economic Development announced that the Ethiopian economy continued to register rapid growth during the fifth year of the Growth and Transformation Plan (GTP) period. The economy is the largest economy in East and Central Africa and has a 6 to 10 percent economic growth between 2004 and 2020 even though the fall in commodity prices has slowed growth somewhat in some African nations, but Ethiopia's economy still soars faster with a forecast of real GDP growth between 7.8 and 10 percent between 2019 and $2023 .^{12}$

With that said, therefore, in terms of moving forward in China-Africa relations, the economic basis should shift to human resources. China has less need for natural resources as its growth model changes towards consumption and services, and its workforce is destined to decline because of demographic trends. Africa, on the other hand, is set for a workforce explosion. It could be a vital destination for Chinese investment, though getting to that positive result will need adjustment both on the African side and the Chinese side.

\section{Imitation Game}

How big is the dividend? One current survey estimate proposes that, on average, a surge of 1 percentage point in the working-age population share boosts GDP per capita by 1.1 to 2.0 percentage points, and savings by 0.6 percentage points (World Bank, 2016a:275). However, the 'bonus' related to demographic changes is not automatic: changes in the age structure are necessary but with insufficient conditions. In 1950, there were 2.5 billion people on the planet. In 2019, there were 7.7 billion (Ritchie and Roser, 2019). By 2060, there will be around 10 billion people in the world -5.2 billion in Asia, 2.8 billion in Africa, 1.3 billion in Americas, 0.7 billion in Europe, and 0.1 billion in the rest of the world (World Bank, 2015). How will this population boom impact African economies? The answer depends on how each African economy responds today with coordinated policies and better institutional framework.

Policy choices, better institutional framework and actions can transform the population of a nation into a healthy, educated, empowered workforce that can contribute to real and sustained economic expansion that lift people out of poverty. As such, to harness the demographic dividend, African economies should focus on both today and tomorrow's youth. However, as it stands now, the continent is balanced on a "knife-edge" between demographic dividend and disaster. For that reason, African leaders are faced with the biggest puzzle today on how to harness their now-or-never demographic opportunity and turn it into agents of sustainable growth and become the new East Asia.

This brings the author to the fundamental question: how do some economies make the most of their demographic dividend and why others do not? Learning from East Asian's economies in attaining the demographic dividend will be a good starting point as well as beneficial in offering required inputs to design policies with specific goals and a timeline for executing them to achieve the objectives. 
The East Asian experience is broadly consistent with the view that population matters (Bloom and Williamson, 1998; Mason 2001). The East Asian nations adopted strong family planning programs, fertility rates dropped speedily, population growth slowed and economic development accelerated. As such, East Asian experience is an example for other economies because East Asian economies offer some of the most compelling evidence to date of the demographic dividend. The East Asian economies were the first to complete the demographic transition outside the western nations. The fertility decline in this region was unusually sharp and the development success of the region is unparalleled (Mason, 2003; Lee and Reher, 2011). This shows how reduced fertility can help create conditions for vigorous economic growth. Declining mortality, followed by declines in fertility, resulted in a speedy demographic transition of the "East Asian Tigers" - Hong Kong, Singapore, South Korea, and Taiwan which occurred over 5-15 years during the 1950s and 1960s. A quarter of these economies economic growth was due to the demographic dividend.

This begs the wider question of how these successful East Asian economies were able to manage the transition. The accumulated evidence points to numerous favorable factors including investment in human capital (notably strong education, family planning and broader public health system), export-led growth, export-oriented policies that increased the demand for labor, high level of domestic savings and an institutional and policy environment that stimulated domestic and foreign investment, and enabled national economies to absorb this boom generation into the workforce in a shorter time period than anywhere else (Bloom and Williamson, 1998; Eastwood and Lipton, 2012; Feeney and Mason, 2001). With more working adults, and fewer children per family in East Asia, resources were freed to permit families and the government to invest more in Child education and health care, offering for a healthier cohort of working adults with skills, ready to move into the economy's expanding job market.

With the present Africa's demographic transition, does it seem that the African century could follow the Asian century? The economic performance of the East Asian economies from the 1960s to 1990s was so exceptional that it is generally called the "East Asian Miracle", while the same years, Africa experienced a period characterized by an astonishing dearth of growth (Presbitero, 2013). It is undeniable that African leaders, remarkably eager to learn from success stories, have been looking east. Rwandan President Paul Kagame hopes to transform his nation's economy into the "Singapore of Central Africa" (Aidoo, 2012). A Kenyan technocrat said, "if you give me a decade, I will give you South Korea, and their Ethiopian counterpart ambitiously said, "We are 20 years behind China" (Fourie, 2011).

Numerous African leaders view East Asia's development experiences as more replicable than those of the west, which appear slow, remote and academic by comparison. This is only but natural as citizens and policymakers have seen, in their own lifetimes, nations like China and Singapore "come of age" in a hostile international environment. The aspiration also makes sense to numerous economists. Development policies aiming to create an environment for speedy economic expansion often rely on the "demographic dividend", which clarified the economic successes of the Asian Tigers. This concept is now creating a sense of optimism for improving the economic well-being of Africa (Gribble and Bremner, 2012).

Demographic economists and demographers point to East Asian miracle experienced between the 1960s and 2000s as evidence that a demographic dividend is indeed positive for economic growth (Mason, 2003). The effects of the demographic dividend operate in two key stages. The first stage occurs when the surge in economic output because of the surge in the number of workers and greater involvement of women in economic activities due to the declined childbearing responsibilities. The second stage occurs when the surge in output that is generated by the boosted human capital investment per child, and augmented investment and savings that government and household make because of augmented incomes and reduced costs of taking care of children.

So, having additional monetary resources and quality human capital can assist in bolstering capital formation as well as the expansion of economic infrastructure critical for attracting capital formation and igniting the promotion of economic expansion. According to Mason (2003), the two stages of 
Table 3. Taking stock of how big are the dividends

\begin{tabular}{|c|c|c|c|c|c|}
\hline \multirow[t]{2}{*}{ Region } & \multicolumn{3}{|c|}{ Demographic Dividends } & \multirow{2}{*}{$\begin{array}{l}\text { Actual Growth in } \\
G D P / N^{*}\end{array}$} & \multirow[t]{2}{*}{ Actual Dividends } \\
\hline & First & Second & Total & & \\
\hline Industrial & 0.34 & 0.69 & 1.03 & 2.25 & 1.22 \\
\hline $\begin{array}{l}\text { East Asia and } \\
\text { Southeast Asia }\end{array}$ & 0.59 & 1.31 & 1.90 & 4.32 & 2.42 \\
\hline South Asia & 0.10 & 0.69 & 0.80 & 1.88 & 1.08 \\
\hline Latin America & 0.62 & 1.08 & 1.70 & 0.94 & -0.76 \\
\hline $\begin{array}{r}\text { Sub-Saharan } \\
\text { Africa }\end{array}$ & -0.09 & 0.17 & 0.08 & 0.06 & -0.02 \\
\hline $\begin{array}{r}\text { Middle East and } \\
\text { North Africa }\end{array}$ & 0.51 & 0.70 & 1.21 & 1.10 & -0.11 \\
\hline Transitional $^{* *}$ & 0.24 & 0.57 & 0.81 & 0.61 & -0.20 \\
\hline Pacific Islands & 0.58 & 1.15 & 1.73 & 0.93 & -0.79 \\
\hline
\end{tabular}

Sources: Mason, 2003

demographic dividend for the South and East Asian nations display the initial demographic dividend that make up 0.59 percentage points per year of the real growth in GDP per effective consumer between $1960 \mathrm{~s}$ and 2000s, while the second dividend make up 1.31 percentage points per year of the growth (see table 2 below). This demonstrates the reason for the heavy investments made by Asian Tigers in health, education, and employment creation paid off considerably, creating the speedy demographic transformation which was an essential condition for speedy economic expansion.

The second dividend (second column) has been larger than the first ${ }^{13}$ dividend, and the combined effects of the two (third column) ranges as high as 1.9 percent a year in East and South Asia. East Asia benefited greatly from the second demographic dividend: The combined effect of fewer children to support and increasing life expectancy is estimated to have led to an increase in gross national saving rates by approximately 14 percentage points ${ }^{14}$

Notably, the "Asian Miracle" was because of demographic transformation which generated development opportunities that East Asian economies seized. The capturing of this opportunity is rooted in the region's effective and comprehensive public policies programs, all-round and coordinated leadership capability, politically determination, self-reliance, and public involvement. The various governments in East Asian economies played a significant role in facilitating the availability of contraceptive technology, ensuring macroeconomic stability, and formulating policies that attached a high priority to education and health. Bearing in mind, Singapore adopted a comprehensive set of incentives and disincentives, and related efforts were followed elsewhere in the region (Yap, 2011). In South Korea, couples' preferences for male children was addressed (Kwon, 2001). In terms of health issue, the region has also made great strides in improving the health situation of its population. Life expectancy increased from 45 to 72 years and the under-five mortality rate declined sixfold during 1960-2018. These benefits were largely due to improved living standards and investment in public health, through targeted health programs and strengthening of health system. With all these coordinated policies implementations, harnessing the demographic dividend was possible and it propelled and transformed the East Asian economies in a historically short time.

For Africa, if the continent was to go through a similar economic miracle, Africa could add as much as US\$500 billion to African economies every year for as long as three decades (Osotimehin, 2015). In 1966, World Bank economists were deliberating on how the continent of Africa could learn and benefit from East Asia's policies, based on the fact that Africa's factor endowments and 
economic structure were quite similar as those found in Southeast Asia in the 1960s (Harrold et al., 1996). While as much as one-third of East Asia's economic "miracle" is attributed to demographic transition, it is interesting that the ratio of working-age people to dependents, is soaring in Africa, is nearly to fall in Eastern Asia (Bloom and Canning, 2011). Depending on the definition used, Africa hopes might amount to wishful thinking just simply because, for numerous economies, the window of opportunity might not materialize before African Union Agenda 2063 target date or could be too short to provide the expected benefit. This indicates that the demographic dividend is neither automatic nor guaranteed. This means nations must earn it by implementing the right kind of policy environment and strategies that will not only accelerate speedy fertility decline, but also ensure that the resulting surplus workforce is well educated, skilled, healthy, and economically engaged.

If the East Asian miracle is to be used as a reference case for African economies, then the former foundations of a robust state and supporting institutions must be made a reality for the latter, still encumbered with significant structural weakness and rampant corruption (Aidoo, 2012). With all these issues, imitating might be a challenge, because, on the other hand, there is an enormous heterogeneity in Africa, making imitation much harder for the continent. For instance, South Korea is a relatively homogenous society and, therefore, its politics is less factionalized and fosters the greater capacity for political consensus-building on policy issues. Most African economies, in contrast, host different ethnic and religious factors competing for influence (Mwenda, 2012).

Arguably, there is no single "East Asian model" or a distinct "East Asian path" either. While economies such as South Korea, Philippines, and Thailand had similar aggregate inhabitants and GDP per capita in 1950, because of South Korea's investment in family planning, education, and health, its GDP grew almost 2,200 percent by 2008, whereas the Philippines grew just 170 percent and Thailand grew almost 970 percent (Osotimehin, 2015).

For African economies to imitate the East Asian miracle and harness a maximum demographic dividend, they should adhere to the five policy pillars in figure 1 as well as these three mechanisms: labor supply, savings, and human capital. Arguably, the implication is that for economic benefits to materialize, it will require strong complementarities among these three mechanisms coupled with coordinated policies and solid institutional settings in key realms that include macroeconomic management, governance, public health, old age security, capital markets, and those that promote labor market flexibility and provide incentives for investment and savings. Also, the provision of a responsive and flexible policy environment where policymakers can continually respond to the unique and changing opportunities and the challenge posed by their specific pattern of demographic and economic transformation will be vital. This will likely be most effective in generating the momentum required to harness a sizeable demographic divided and enter a phase of accelerated economic growth. It is in this context, the author turns to the next part of the paper to look at the implications of the demographic dividend for Africa in these three main areas: savings, human capital, and labor supply.

\section{SOCIO-ECONOMIC IMPLICATIONS OF DEMOGRAPHIC DIVIDEND FOR AFRICA}

Though Africa population is still snowballing, the changing age structure provides it with an opportunity to avail for economic expansion. As such, when a nation finds itself with such a shifting age structure, there are four areas where benefits, or dividends, are typically found such as labor supply, savings, human capital and economic growth. However, the future gain will be possible assuming suitable social, political, and economic policies be matched with improvements in education, health, and family planning. Such a focus on Africa's young population will guide the continent Agenda 2063 towards the "economic gift" ("economic gift" means that the labor force is growing more rapidly than the population that is dependent on it, creating a window for faster economic growth and family welfare) of a demographic dividend allowing for the gains of labor supply, savings, human capital, as well as economic advancement to follow. 
In theory, at the micro level, this transition can result in better living standards for families and higher incomes per person while at the macro level, it can have significant gains in the economic development of a nation. So, rather than attempting to treat the demographic transition as the source of bringing about economic development in Africa, it will be better to see what opportunities it offers and what are the implications of this offer for the continent. If opportune policies are not adopted as mentioned initially and efficiently applied, the opportunity would be missed. Failure to grab the opportunity would not only be a letdown on its own but adverse effects could also set in instead.

\subsection{Savings}

Research reveals that lifecycle variation in productivity leads individuals to vary their savings over a lifetime to accommodate their consumption (Lee et al., 2000; Duffy and Li, 2018) Demographic transition, therefore, encourages savings which in turn can boost the nation's ability for investment and growth. Leff (1969) did pioneering work in establishing a relation between dependency ratio and savings, and found an inverse correlation between the two. Notably, the basic logic behind the negative correlation being that young and old consume more than they produce, while working-age people produce more than they consume and can save, which can contribute to the economic expansion of a nation (Bloom, et al., 2001; Deaton and Paxson, 2000, 1997; Williamson and Higgins, 2001; Bloom and Canning, 1999; Bloom and Williamson, 1998; and Kelley and Schmidt,1995; United Nations, 2019; IMF, 2019b; WEF, 2019). Nonetheless, in his later study, Kelley (2001) did not concur with this logic. But based on the capability and willingness to save, Mason (2005b, p.22) affirms that "the changes in age structure define possibilities, but by themselves do not determine the results".

For the past two decades, and especially the years since the turn of the millennium, have represented a period of sustained economic growth for the African continent, with growth rates often exceeding 5 percent annually (Zamfir, 2016). The demographic transition can potentially increase individual and national saving rates through three main channels. First, income per capita may rise as more public and private resources are put toward education. Second, saving rates become positive when individuals are working and reach their peak in their mid-career (Modigliani, 1990; Bloom, 2019), such that changes in age structure affect aggregate saving rates even if individual age-specific behavior remains the same. Finally, new cohorts of workers are expected to have fewer children and to live longer than older cohorts. Having fewer children may result in a shift from spending to take care of older people to financial savings, while a longer lifespan implies a greater need for savings to finance consumption during a longer period of inactivity during old age (Schultz 2004; Bloom, 2019).

At the macro level, higher saving rates can lead to higher levels of investments and faster economic advancement. At the household level, they imply higher self-insurance and income protection. Evidence demonstrates the power of savings during demographic transitions as a driver of economic advancement. For example, all the Asian Tigers enjoyed a surge in labor force per capita because of the changes in the working-age share of the population and female participation as well as savings and investment. The private saving rate in Taiwan, China, rose from about 5 percent in the 1950 s to well over 20 percent in the 1980s and 1990s (Canning et al, 2015). Saving rates vary by age and are highest for Taiwanese household with heads who are between 50 and 60 years old. The rise in saving in Taiwan, China and other Asian Tigers can be clarified in part by changes in the population age structure and in part by upsurges in life expectancy, which surge the incentive to save for retirement.

For the elderly, a wide range of approaches are employed to fund consumption globally, with some nations depending on private savings, others on government transfers, and others on private or family members. Family transfer to finance the consumption of the elderly are significant in East Asia. In most nations and regions globally, nonetheless, finances tend to flow in the opposite direction as the elderly make transfers to younger family members. In Sub-Saharan Africa (SSA), there are few statistics on age-specific income and consumption. In South Africa, despite a government-offered old-age pension, the major source of funding for old-age consumption is private savings (Oosthuizen 2013). It appears likely that people in most poor African nations rely on family transfers and, to some 
degree, private savings. The necessity for income in old age implies that working-age adults, and especially older working-age adults, typically save for retirement, although this hinges heavily on the incentives in the public pension system (Bloom et al., 2007).

In Asia, soaring working-age shares in the population were connected with a boom in savings and investment. The effect is anticipated to be less dramatic in Africa, at least in the short run. In aggregate statistics, savings are higher when the working-age share of the population is larger. But there is also a robust income effect, because national saving rates are very low in low-income nations. In household statistics for every poor African economy, there is little proof of life-cycle savings. For the poor, most savings are precautionary, in the event of the health or income shocks in the near future, and are accumulated in physical rather than financial assets (Aryeetey and Udry, 2000). As such, no matter what the method of estimation is, two things are nearly certain. One, there is an inverse relation between dependency ratio and savings, and two, which is more significant, that savings are important at both the national and personal level. At the national level, savings are needed to finance investment and growth, while at the personal level they are important to maintain a standard of living through the period of retirement.

Increased life expectancy and the anticipation of a prolonged retirement are also likely to affect domestic savings rates (Bloom et al. 2007; WEF, 2017; Crawford et al., 2020). To the degree that older workers accumulate savings rather than bank on State "pay as you go" pension schemes or family support, a second demographic dividend may arise, provided that savings are productively invested (Mason and Lee, 2006). This is truer given that Africa does not have a sound state-sponsored social security system and individuals are primarily reliant on their own savings during older ages. The importance of these considerations is underscored by the critical significance of savings for development. "Without the creation of a surplus for investment, there is no way for economies to escape a low-level subsistence equilibrium (World Bank, 2006). Ageing of population is the inevitable end of the demographic transition, and Africa, albeit slowly, is moving towards it.

In the absence of any state planned old age security system and the existing low saving rates in the nation, the demographic dividend can become a demographic nightmare for most of older people if they do not upsurge their savings during their prime working-age. With reference to savings, worth mentioning here is the phenomenon referred to as the 'second demographic dividend' in the literature (Lee and Mason, 2007). Differences can exist among the impacts of the changing age distribution at different phases of demographic transition. The snowballing old dependency ration, unlike the soaring ratio of children, can lead to a substantial upsurge in assets per capita and in capital per worker (Lee and Mason, 2007). The 'second dividend' depends not just on the lifecycle earnings and consumption of the ageing population but also their asset accumulation and saving behavior. Augmented savings therefore not only secure an elderly as an individual but also offer the potential for a 'second dividend' to the economy.

\section{Human Capital}

Human capital and demographics are critical drivers of economic growth. Demographic change affects the size of a nation's total population, working-age population, and workforce. Human capital development, the result of investment in education and health, is itself a goal for the welfare and empowerment of the people, and a key component of the Sustainable Development Goals. It is also a vital determinant of economic growth, as investment in human capital raises labor productivity and contributes to technological headway, along with investment in physical capital, innovation, and increased efficiency linked with policy and institutional reforms.

Several studies have revealed that investing in human capital, measured by various indicators, is positively linked with the pace of growth. ${ }^{15}$ Also, bearing in mind, improving the quality of human capital can offer an alternative route to faster growth in Sub-Saharan Africa (SSA) ${ }^{16}$, where physical capital is relatively scarce. As a result, high levels of investment in human capital can turn developing and emerging economies into factories of talent not the 'cheaply-staffed workbenches' 
of the developed world. Therefore, it is premised that demographic transition has a significant effect on investment in human capital. Snowballing life expectancy makes parents invest more in their children's human capital as the premium for higher education surges and lasts longer. Therefore, the labor force becomes more productive, gets higher wages and there is an improvement in the standard of living (Bloom et al., 2001; ILO, 2019).

East Asian economies have gone far in expanding education over the past five decades - motivated by public investment, policies that broaden access, and education reforms. Almost all East Asian economies attained universal or near-universal access to primary education. Most of them also attained universal or near-universal access to secondary education, significantly expanded technical and vocational education and training, and tertiary education.

With that said, it is worth noting that with each passing time, the knowledge content of nearly every industrial field is becoming richer, and technological thresholds of most industrial activities are soaring. The capabilities of the labor force must soar commensurately. Not just developing but also developed nations are recognizing that if knowledge is the arbiter of economic expansion, then human capital must rank among the highest priorities for economic policy making. ${ }^{17}$ As such, human capital is identified as an "engine of economic growth". Human capital contributes to economic advancement in two ways. First, the human capital embodied in a human being upsurges that person's productivity, leading to a surge in total production and to economic advancement. Second, the human capital embodied in a person also contributes to the productivity of all other factors of production. These are respectively known as "internal" and "external" effects of human capital (World, 2002). As such, it cannot be emphasized enough that it is not the quantity but the quality that is more vital for human capital formation and economic growth (Dupreiz, 2003).

Speaking of human capital, during the author's discussion with retired Brigadier General, Saleh Bala, who is the President at White Ink Institute for Strategy Education and Research (WISER Abuja, Nigeria, he said, "interesting how Africans pride in the number of registered voters and celebrate victories over votes cast, but never accept statistics on regional out-of-school children and poverty indices". ${ }^{18} \mathrm{He}$ voiced his concern based on the fact that there are about 203 million people above the age of 15 years who are still illiterate in sub-Saharan Africa (Xinhuanet, 2017). Half of the number is concentrated in the Democratic Republic of Congo, Nigeria, Ethiopia, Kenya, Uganda, and Tanzania. On top of that, African Development Bank declares that 25 percent of African youth are illiterate -the highest rate out of any region in the world; nearly 133 million young people, or more than half of Africa's young population, are uneducated (AfDB, 2011).

UNESCO also predicts that Africa will be home to half of the world's illiterate people in the years ahead; the report shows that there are still 750 million illiterate adults (UNESCO, 2017). Compared to other regions of the world, sub-Saharan Africa has high illiteracy levels given that sub-Saharan Africa is home to one-seventh of the world's population but 27 percent of the illiterate global population (Xinhuanet, 2017) As a result, the region is far behind other regions because it has the world lowest secondary school enrollment rate that is lower than 5 percent. ${ }^{19}$

This low enrollment rates in Africa is associated with Western policies toward the continent. This is because the conditional loans from the West, and specifically, institutions like IMF and World Bank, have had a further negative impact on human capital which has affected the African education system. World Bank obliged African nations to center their spending on primary education and not necessarily on higher education (Jonker and Robinson, 2018). This resulted in the weakening of standards at secondary and universities enrollment rates in the pre-colonial era. This situation was further compounded by the marginalization of universities by despotic African leaders, who saw them as incubators of resistance and opposition, rather than as centers of knowledge. One of the discreditable World Bank's policies was to insist for decades that it is not essential for Africa to focus on higher education, but on the school sector, the implication of which was that African nations were never going to completely develop (McGregor, 2015). With these despotic African leaders believing the World Bank policies shows that there is a strong case for African leaders taking greater responsibility 
for their own failures with regards to prioritizing human capital investment; this shows why the youth enrollment in African nations has been low.

Notably, investment in human capital specifically education appears to be key to the economic success of the East Asian economies (Wood and Berge, 1994). Wood and Berge argued that as, after all, trade policies are the same globally, it is human resource endowments that matter more than anything else. East Asian economies have proved that to be true because nowhere is the value of human capital to development more apparent than in East Asia. To prove this, the top four (of 157) spots in the World Bank's recently introduced "Human Capital Index" (World Bank, 2018; Jong-WHA, 2019) - a composite measure for survival, learning-adjusted years of schooling, and health - are occupied by East Asian economies: Japan, Hong Kong, Singapore, and South Korea. This spectacular achievement in terms of economic growth and human development, including education made them enviable for several developing (and probably some developed) economies. Because of East Asian economies huge investment in human capital, one can clearly identify an "education miracle" behind the economic miracle (Haq and Haq, 1998, p.31).

For Africa, the question facing the continent right now is to first get all its children to school and it is only then, with the passage of time, that we can hope for them to reach higher levels. Nations in East Asia took full advantage of the demographic dividend because they made timely investments in primary and then secondary education. The outcome of this investment in these East Asian economies in education reflected in more productive labor which enables them to seize the opportunity offered by their various demographic dividend (Phang, 2005; Mason, 2003, 2005a). Just by having the school growing population in the "right" proportion does not make the demographic benefits automatic. In the absence of any planning, it can only result in large segments of the population which are uneducated, unskilled and ill-equipped to adapt to the changing world conditions, at both micro and macro level.

The point to ponder here is that if universal enrolment were not achievable in Africa with the current size of the primary school growing population, then what could be expected with the increased numbers that it would encounter in the coming decades? And with children not getting enrolled at the primary level there can obviously be no ground for population getting a higher education.

The 'Asian Tigers' did not set out to harness the demographic dividend, nevertheless, the leaders realized that their nations were not going to develop if they continued to sustain socioeconomic systems that propagate low status of women and lead to high fertility and high child dependency burdens; that developing quality development infrastructure that balances rural development and value addition chains in agriculture and industrial as well as service-based urban economic; that transformative education is the ultimate tool for building quality human capital and engineering the innovation and vibrant private sector that is needed to create quality jobs and accelerate inclusive economic growth; and that all these cannot be attained if African economies do not enforce accountability in use of public resources and address corruption, while ensuring efficiency in service delivery.

Human capital, effectively harnessed, would enable African economies to surge allocative efficiency and maximize the returns from (initially) limited supplies of physical capital. Moreover, it is only via the application of knowledge that African economies will be able to cope with potentially crippling threats from prevalent diseases, expanding youthful and urbanizing populations, and impending climate change. Only by raising the rate of investment in human capital can the region reach and sustain the level of economic performance it needs to generate an adequate volume of employment for expanding populations, to attain various Sustainable Development Goal (SDG) targets, and to grow to narrow the economic gap between Africa and other developing regions. Africa's per capita income could quadruple by 2050 if such timely investment in human capital were complemented by policies that foster job creation (UNICEF, 2017).

As a result, improved human capital is a precondition for cashing in on the demographic dividend as the sources of higher productivity are becoming increasingly dependent on science-based knowledge and information applied to production. There is a snowballing shift from traditional agricultural and manufactured products to more sophisticated services and agricultural and manufactured products. 
Changes are emerging in the way economic activities are organized as a shift is taking place from a mass, standardized production to flexible, customized production. All this gives a significant edge to these nations that have a labor force having skills and knowledge to adapt to the changing market conditions. A continent like Africa that is yet to solve its primary schooling issues can at best have some patches of success but not expect to take full advantage of what "demographic dividend" has to offer.

\section{Labor Supply}

The demographic transition goes through a phase when it contributes to the labor force in two ways. One, the number of people in the working-age gets bigger, and two, women are more likely to enter the labor market as fertility level declines. However, it depends on the ability of the market and workers to make able use of this scenario. As of 2015, some 198 million young people were in the 15-24 age group in Africa, and this is expected to more than double to 413 million by 2050 (UNDESA, 2015) (see figure 6). Nations in the region exhibit the variation expected given their position along with the demographic transition. For example, the number of young people will quadruple in Niger by 2050 , while it will remain constant in Estwatini (former Swaziland) and Lesotho and decrease in Mauritius, Cape Verde, Seychelles and South Africa. The share will begin to fall from 2030 at a regional level but very minimally - most of the decrease will take place after mid-century.

Conversely, the share of the total working-age population (15-64) will continue to surge throughout the 21 st century -climbing 8 percent points by 2050 (a surge of over 800 million) and 10 points by 2100 - making clear the fundamental reason for optimism around the demographic dividend (Samman and Watkins, 2017). The rise in the number of young people is a useful proxy for the potential number of new entrants into the labor market, though this varies particularly with female participation levels.

Speaking of female participation in the labor force, the rapid economic growth of the Asian Tigers was fueled in part by a surge in female labor force participation (Canning et al., 2015). Although the global labor force participation rate has remained stable over the past two decades across all regions, it has remained significantly higher in Sub-Saharan Africa (SSA) at 63 percent in 2010 and 64 percent in 2014 compared to other regions as display in figure 8. Nevertheless, the data in figure 8 displays a wide gap between male and female labor force participation within the SSA region between 1990

Figure 6. Fresh entrants into the labor market (15-24 years) and working-age people (15-64 years) respectively 2015-2100

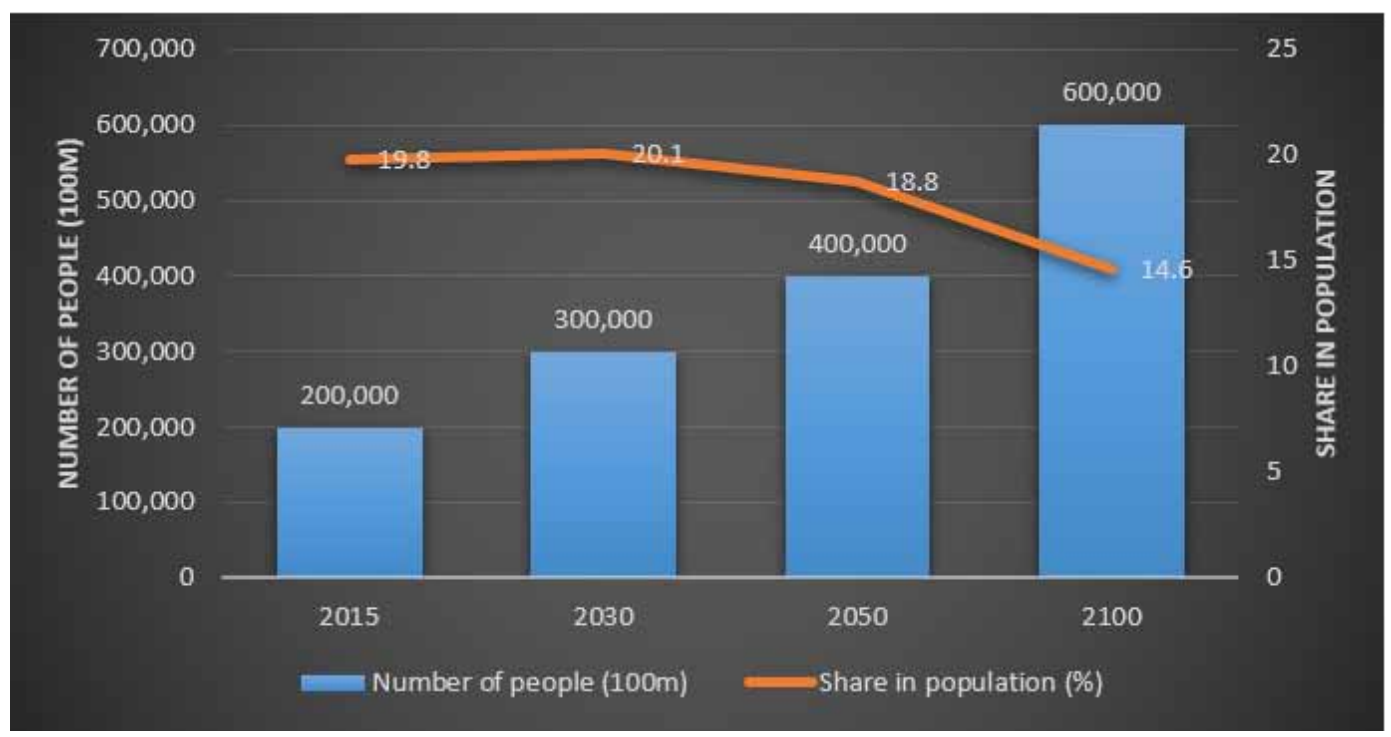


Figure 7.

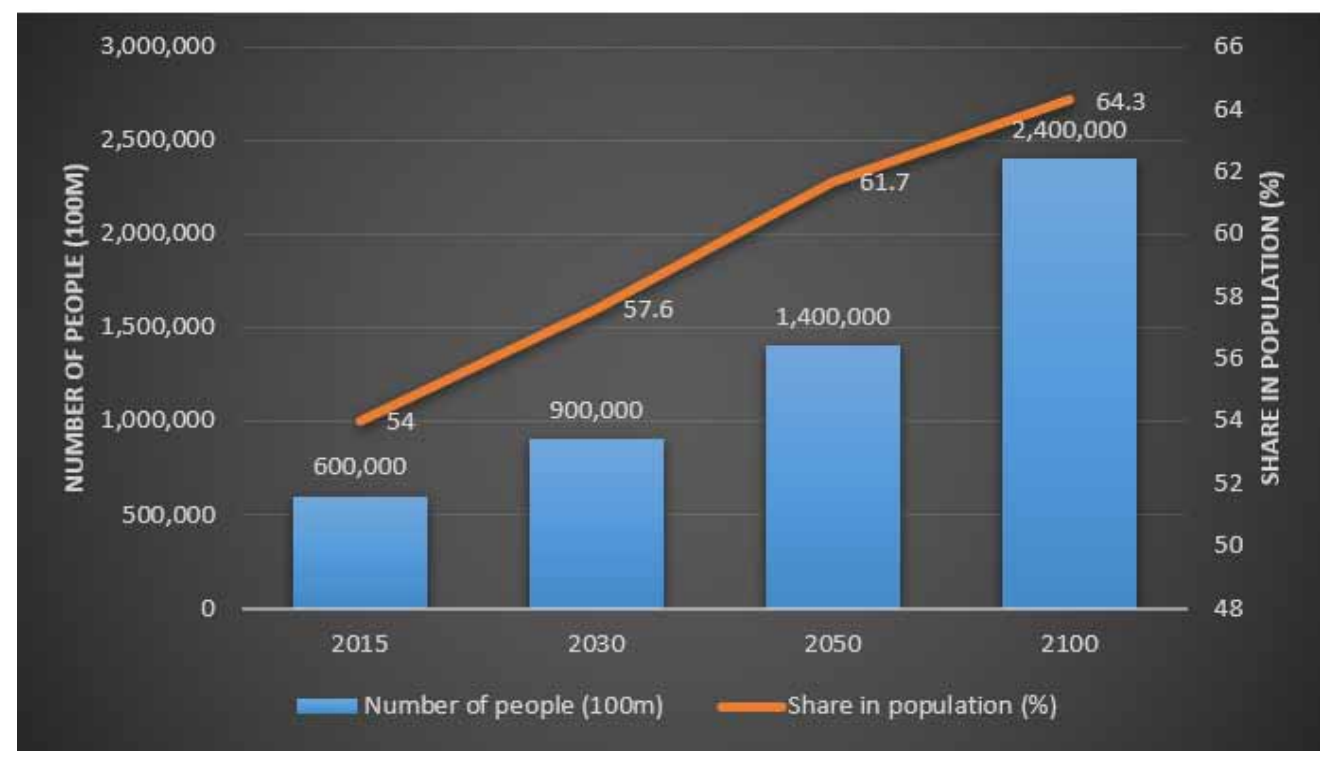

Source: Author's illustration based on UNDESA (2015) statistics

Figure 8. Female Labor Force Participation Rate by Region for 2010 and 2014

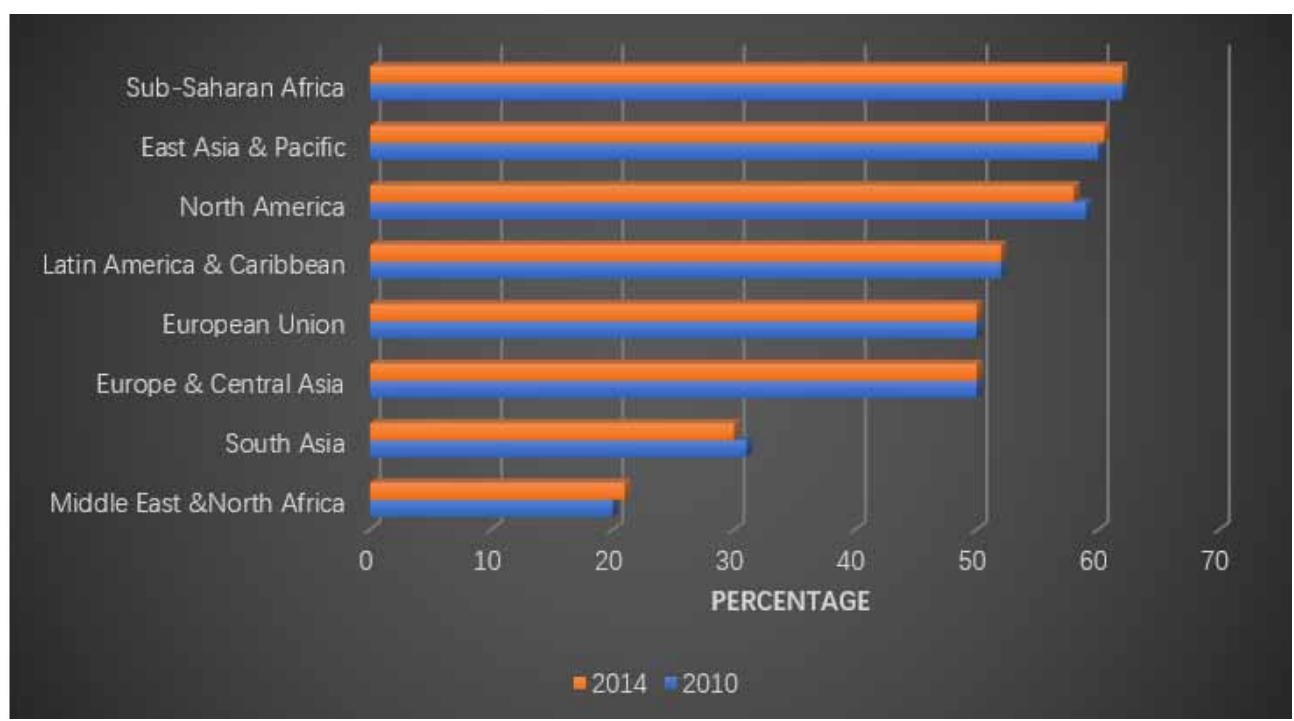

Source: World Bank (2016b

Notes: World Bank development indicators of female labor force participation rate is defined as the proportion of the female population ages 15 and older that is economically active: all females who supply labor for the production of goods and service during a specified period (ILO). 
Figure 9. Annual Labor Force Participation rate by Gender in Sub-Saharan Africa, 1990-2014

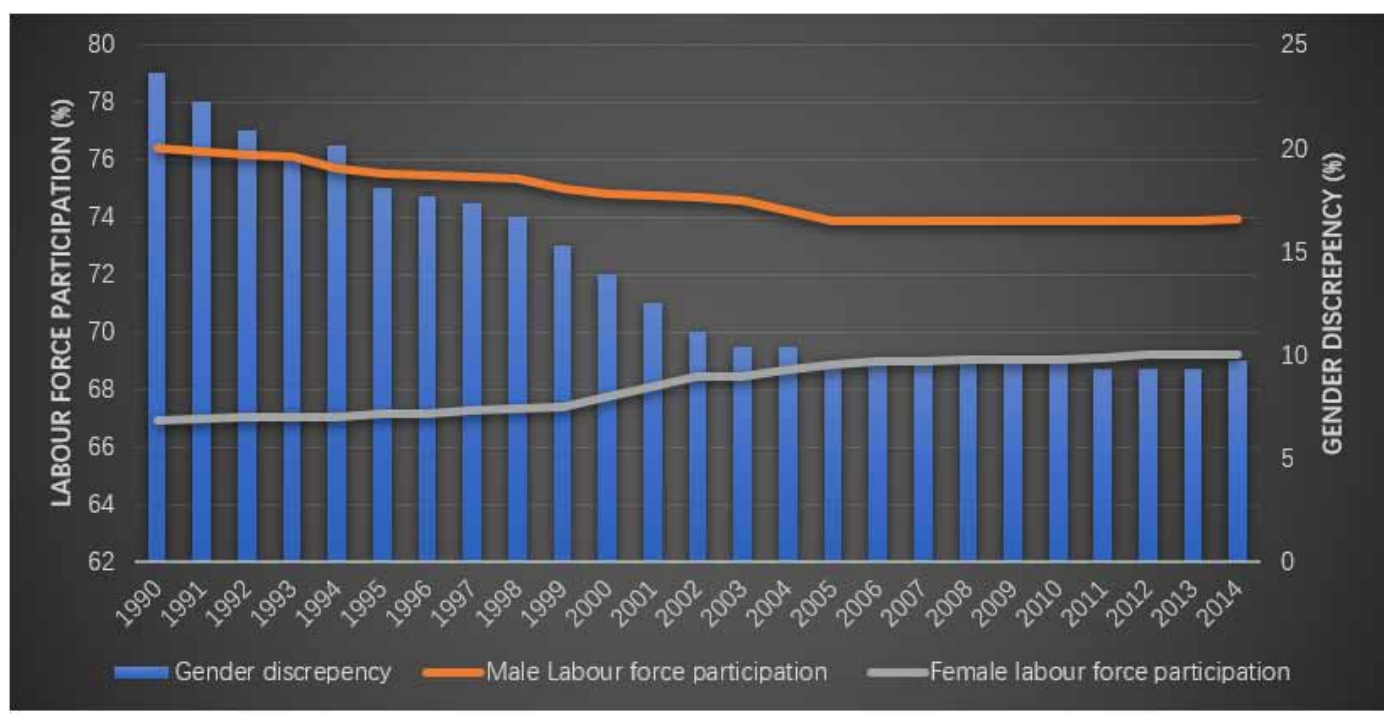

Source: World Bank (2016b).

Note: World Bank development indicators of labor force participation rate is defined as the proportion of the population aged 15 years and older that is economically active (ILO).

and 2014, with male participation significantly higher than female participation. Although male labor force participation has declined from 80 percent in 1990 to 76 percent in 2014, it was still significantly higher than female labor force participation (by 10 percent) by 2014 .

Bearing that in mind, more significant workforce participation gender gaps remain in nations such as Mauritius, Mali, Cote d'Ivoire and Nigeria as display in Figure 10. With these differences, it is worth noting that a lesser percentage of females in working-age are active in the labor market.

This point to the large potential of snowballing female in labor participation within the region, and means a waste of resources that could have been harnessed because of the opportunity the changing demography is offering the continent.

Another interesting insight in figure 8 is the non-decreasing gender gaps in the labor market over the past 10 years in the SSA region. The data in figure 8 displays that from 1990 to 2003, the gap between male and female participation declined from 21 percent to 14 percent. Nonetheless, between 2004 and 2014, the differences between males and females in the labor market remained at 13 percent. This is attributable to a combination of cyclical and structural factors. In a case where the trends are attributable to the cyclical factors, as the economy recovers, there should be an improvement in the participation rates in the market. Nevertheless, if the trends are due to structural factors such as legal and policy restrictions, then participation rates would improve via the adoption of the appropriate policies and removal of the legal restrictions on gender disparities, therefore, seizing the 'dividends' of the changing age-structure.

Female labor participation can be a driver of economic development. As more women enter the labor market, economies tend to grow (Verick, 2014). SSA alone is likely to account for almost two-thirds of the growth in the world's working-age population between 2015 and 2050 (World Bank, 2016b:190), and the productive employment of these people is a major factor underlying the presumed demographic bonus.

On the other hand, in terms of linking SSA evolving demographic to evolving migration, there is a risk that inadequate employment expansion will perpetuate poverty and unemployment and, in 
Figure 10. Economic Activity, unemployment and inactivity among Africa's working-age population

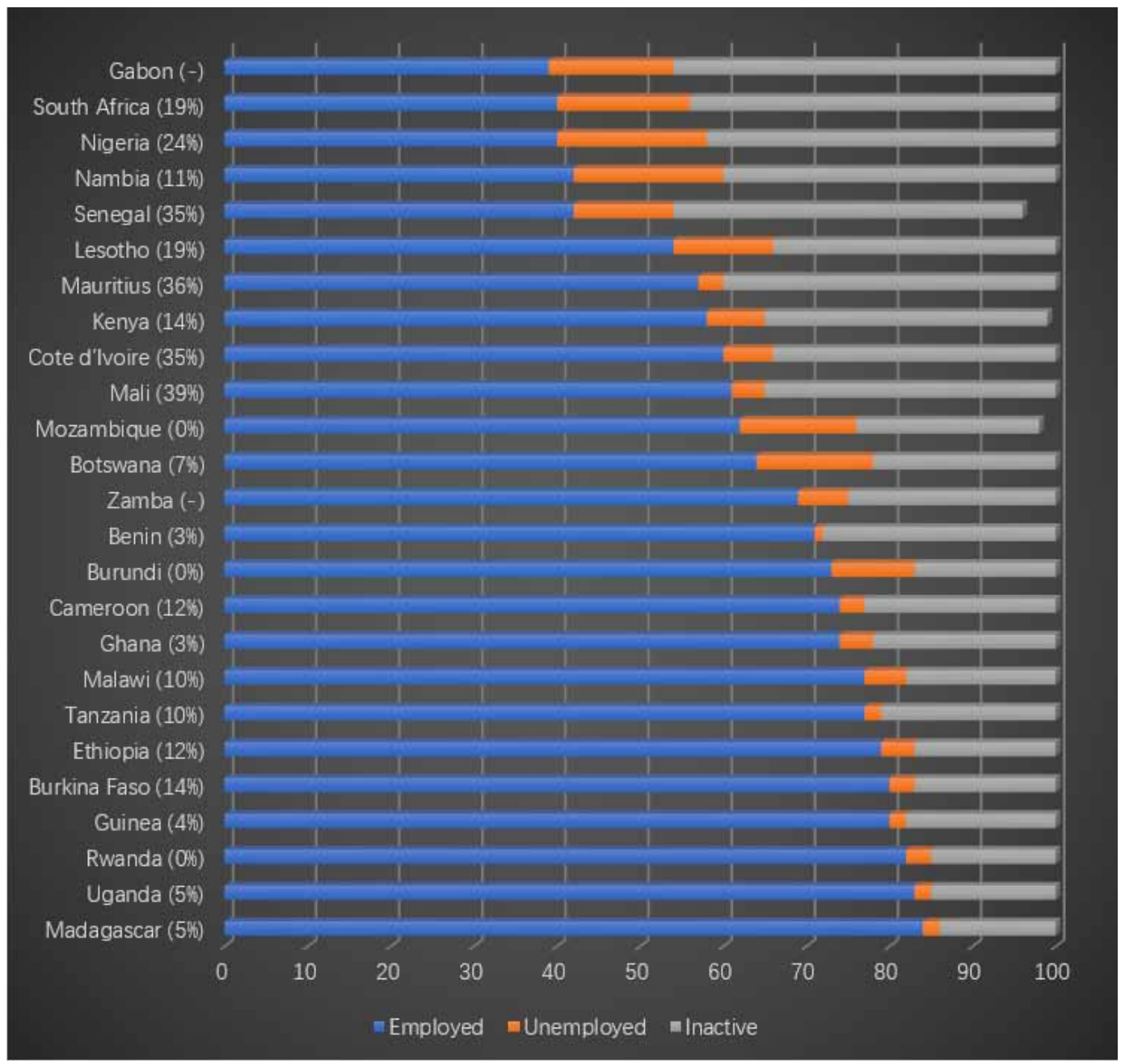

Source: World Economic Forum, 2017

Note: Percentage in parenthesis after country names refer to workforce participation gender gap. For example, Madagascar has a 5 percent gap in women's labor force participation

turn, migration is likely to surge. The demographic shift will be the result of a search for what these migrants think would be better and easier living for them. A recent IMF study forecasts proposed that the ratio of SSA migrants to the population of their novel homes in OECD nations will surge six-fold in the coming decades from 0.4 percent in 2010 to 2.4 percent by 2050 (Gonzalez-Garcia et al. 2016) (see Figure 11). Migrant workers can have a positive impact on economic advancement in receiving nations those where the population is ageing speedily. They also bring additional tax revenues and much needed social contributions in their new home nations to support retired workers. At the same time, the flows of remittances sent back to their nations of origin will continue to support the living standards of relatives. This, in turn, helps alleviate poverty and will continue to play a significant role in the economy as a stable source of foreign earnings. 
Figure 11. Population Shift: SSA Migrants in OECD Countries (Stocks as share of population)

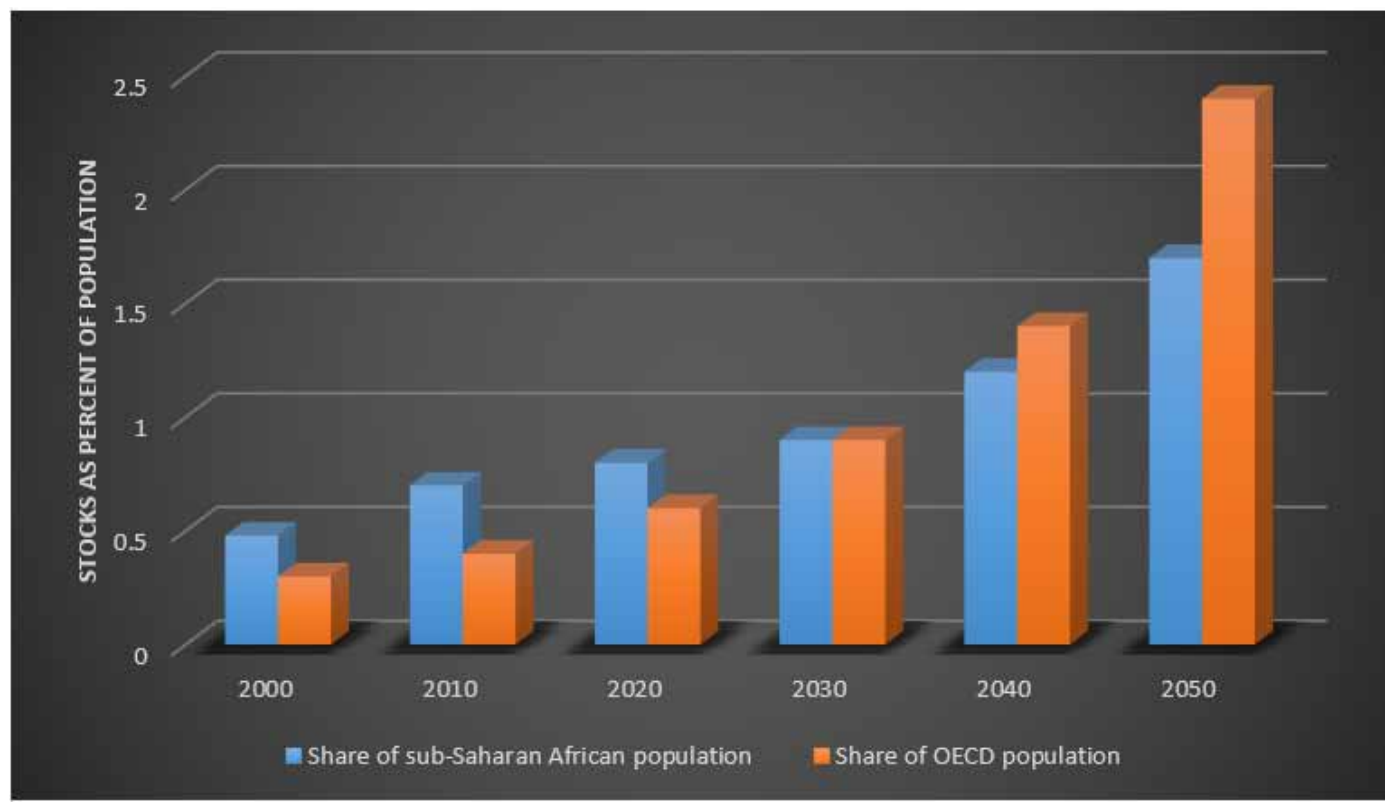

Source: Gonzalez-Garcia et al. 2016

Note: OECD = Organization for Economic Co-operation and Development

As such, the simple fact is that without creating the "youth bulge", that later turns into a "workingage bulge", there is not going to be a demographic dividend to talk about in most African economies. But incorporating these young people into labor markets will be challenging; youth unemployment level in 2017 was already at 13 percent in the region -almost twice as high as the 7 percent figure for SSA's working-age population (World Bank, 2017). All these can pose a dilemma for policymakers in African nations as well as has serious implications for these nations as the logical end of demographic transition is ageing of the population. Shrinking job opportunities among young population stress the need for flexibility not only in the labor market but also in the labor force to cope with the scenario that is bound to take place once the 'echo generation' gets old.

Full benefits provided by the demographic dividend cannot be gained unless labor force participation rates are improved, but augmented labor participation implies generating employment for these vast number, which by no means is an easy task; this is, however, only part of the story. In poor nations and among poor communities, a dearth of productive work may be more aptly measured by the share of people who are underemployed, and/or working in low-productivity, low-paying jobs such as those in the informal sector. In low-income SSA, the informal sector -both self-employment and agricultural employment - accounts for almost 90 percent of the 400 million existing jobs (IMF, 2015;26). To maximize productivity surge, an estimated 18 million high-productivity job annually through 2035 will be needed to absorb new entrants (IMF, 2015;25-26). The danger is that, without sustained productivity surges, these workers could end up working as unremunerated family laborers or in low-productivity, informal work (Canning et al., 2015).

Of concern is many young people, and particularly young women, that are Not in Education, Employment or Training (known as 'NEETs'). Statistics from 2000 onwards is not accessible for nine nations in SSA, but it hints at a sizeable problem: on average across these nine nations over 10 percent of male youth and over 20 percent of female youth fell into the NEETs category. At the 


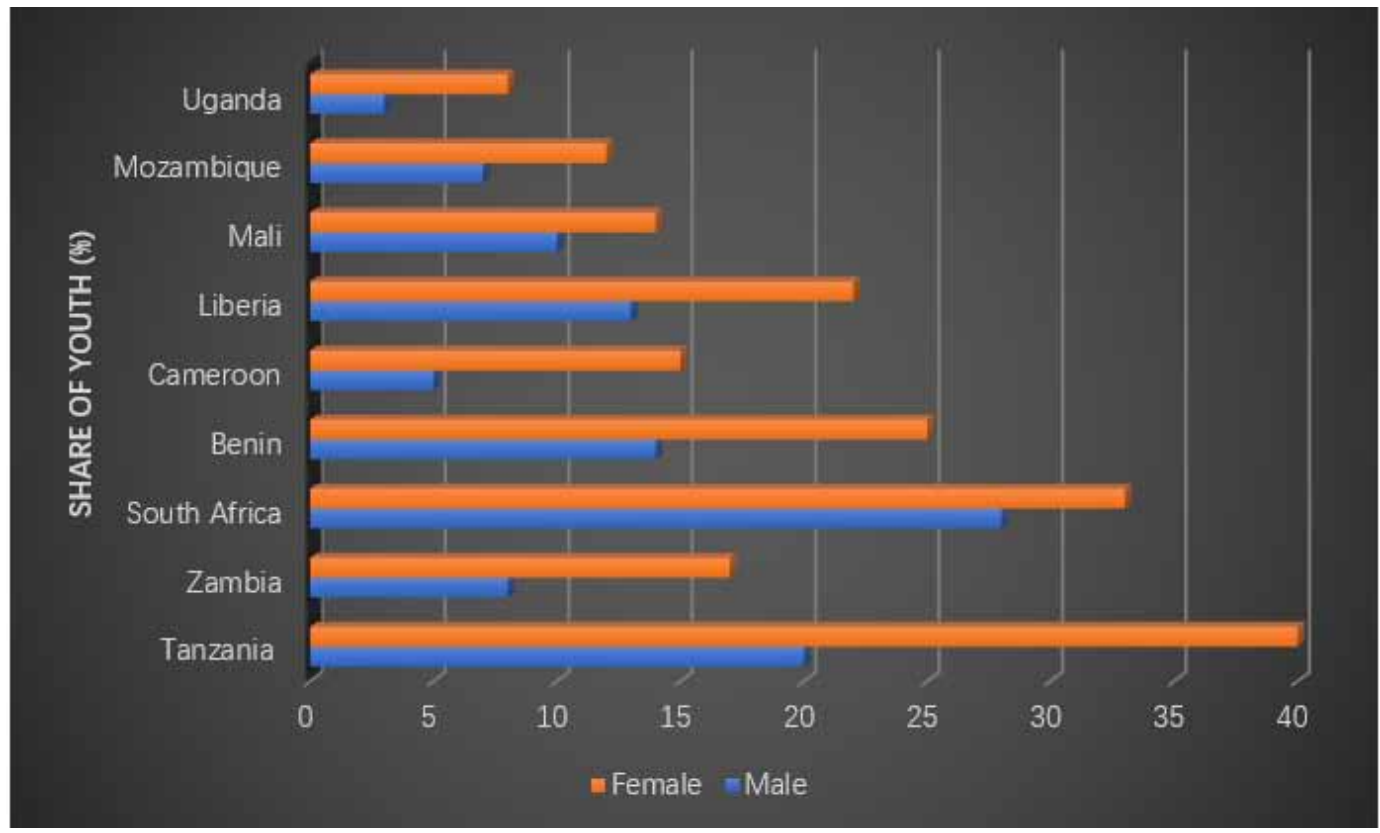

Source: Author's illustration based on the International Labor Organization (ILO) Statistics 2017

extreme, the share was nearly 30 percent for young men in South Africa and 40 percent for young women in Tanzania (see Figure 11). If African nations continue to build on the hard-won development gains, the demographic dividend could account for 11 to 15 percent of gross domestic product volume growth by 2030, while accounting for 40 to 60 million fewer poor in 2030 (Ahmed et al. 2014). The gains can become much more substantial with even better educational outcomes that permit African nations to catch up with other developing nations. If the skills share of Africa labor supply doubles because of improvements in educational attainment, from 25 to about 50 percent between 2011 and 2030 , then the demographic dividends can expand the regional economy additionally by 22 percent by 2030 relative to the base case and alleviate poverty by an additional 51 million persons (Ahmed et al. 2014).

\section{CONCLUSION AND POLICY IMPLICATIONS FOR AFRICA}

The paper examines the diverse ways the continent of Africa can harness its demographic dividend, by arguing that for African economies to imitate the East Asian miracle and harness a maximum demographic dividend, the continent needs to adhere to the five policy pillars displayed in figure 1 as well as these three mechanisms: labor supply, savings, and human capital. The implication is that for economic benefits to materialize, it will require strong complementarities among these three mechanisms coupled with coordinated policies and better institutional framework.

Africa's population is very youthful and the region projected demographic profile is eye-catching which present a huge window of opportunity to reap a demographic dividend. The demographic dividend - the one-time economic bonus that can arise if conditions are right, from a decline in fertility rates - could matter a lot for African nations. More so, snowballing number of people entering working-age in Africa can act as a double-edged sword -if they do not enter the workforce the very logic of "demographic dividend" is defiled, but if they do become economically active, then it will possess a big challenge to the nation's economy in terms of offering them profitable jobs, health cares, and incentives for savings. 
As a result, main areas of focus in this regard includes education, public health and family planning, incentives for savings, and most importantly the creation of an economic environment that encourages employment creation and labor flexibility. More so, if African economies are to harness their demographic dividend via the development of natural resources, then the government will need to successfully navigate the revenue management issues and prioritize investments from natural resources revenue into health care, education and nutrition. The timing and magnitude of natural resource discoveries will determine the extent to which a nation's energy sector will be able to create necessary jobs for the demographic transitions. The impact of these jobs will be modest, however, due to the capital-intensive (as opposed to labor-intensive) nature of energy projects.

In terms of applying the imitation game strategy, African nations need to know that East Asian economies took complete advantage of their demographic dividend. Successful human resource investment was the basic feature behind their cumulative employment and labor productivity growth. Equally vital were policies that first stressed primary and then secondary education. They had a successful research programme that led to enormous profits in agricultural yield and there was no need to absorb extra employees into the sector that had no capacity to offer more jobs at higher wages. These economies were successful at creating novel industries and employment in the service and manufacturing sectors of the economy. The region took advantage of an encouraging trading environment, but followed successful export promotion policies as well. Wise macroeconomic policy created an investment-friendly environment that ensured the availability of capital required to surge manufacturing capacity initially via overseas financing and then from domestic sources.

Lessons are to be learnt by African economies from East Asian experience, and utilized these lessons after adapting to emerging world and local conditions. There is a need to rethink the whole growth strategy in Africa, and implement what Hague (2006) calls a "meritocratic framework" in which success is measured by the market and government's efficiency and gauged by its capability to develop institutions that aid the market. Although Hague is talking only about the economic activity when he asserts that "institutions need to be built that preserve individual freedom, offer security, and facilitate market transactions. The government merely offers these institutions, permitting markets to determine where economic activity goes (Hague, 2006:26), but this was applicable to other fields as well, including education and health, improvements which are crucial to reap the benefits of the demographic dividend.

The recent roadmap for China-Africa cooperation in the new era is the one Xi Jinping recently titled "walk together towards prosperity" came at an opportune time for deepening demographic dividend-related cooperation between China and African economies. This is because it comes at a time of transition when frontier and less resource-motivated African economies are emerging as potential candidates and could represent a "New China" in terms of low cost labor and favorable demographic profiles, which are top drivers of manufacturing competitiveness, subject to good policy choice, technology shifts and the broader trends of the world economy.

If African nations want to capture fresh economic opportunities in higher-value-added productive activity from China, improvement of the quality of human resources especially those in productive ages, is imperative, because education and training are important to determine the productivity of human resources. This cannot be gained by just improving basic enrolment rates but by providing relevant and quality education. Interventions are required to upgrade the educational system by including provision to develop skills to meet the demand of a more flexible workforce in the new economy.

Savings can enable a nation to grow quickly because savings enhance growth in economies that are not too close to 'technological frontiers' but the two, saving and growth, do not have any correlation in the economies that are close to the frontier. "Local saving matters for innovation, and, therefore, growth, because it permits domestic banks to co-fund projects, and therefore, attract overseas investment. However, in Africa, savings have always been low because of large amounts of capital flight resulted in response to augmented government control over resources. Such private savings systems are, however, not conducive to growth as are those that offer liquidity to the banking system. 
Liquidity of the domestic banking system helps attract foreign investors to bring in their frontier technology that triggers total factor productivity (TFP) and productivity growth.

Notably, equal opportunities should exist for both sexes, and reducing, preferably abolishing, the gender gap that exists in education and labor force is essential. By improving their educational level, along with lowering fertility, women should be encouraged to have a larger share in the labor market. Effective capitalization on the demographic dividend is not possible with half the population excluded from the process. Employment generation to accommodate the cumulative number of persons in working-age would be a major issue for the continent. Novel areas need to be explored to offer jobs to the ever-growing number. The demographic dividend is inherently transitory in nature.

Age structure will continue to be a vital force in the continent for next five decades. How economic growth is shaped by demographic changes in the coming years will depend on what policies Africa put in place because there is no "silver bullet" package of policies that guarantee a dividend, but basic socio-economic indicators and supportive -alongside youth bulge-have correlated with attaining the dividend in Asia. Adapting foreign models to local social, historical and cultural realities is essential.

African economies need to look not just outside but also within at their own economic and developmental histories, and reflect on these successes and failures, and on what they mean for their own development strategies. They are clearly in a better position to achieve and maintain economic growth than at any time in their post-independence histories, and there is no doubt that Africa has potential required to harness the demographic dividend. However, time is running out to put suitable policies in place, the absence of which may result in large-scale unemployment, immense pressure on health and education systems. African leaders should be hard-nosed and oriented towards implementation and sustainable in first identifying and then agreeing the best policy mix and governance structures for realizing African wins. Unless they do all these at present and in future, Africa's demographic transition narrative might just be a tale of missed opportunity. 


\section{REFERENCES}

AfDB. (2019). African Economic Outlook 2019 - Macroeconomic Performance and Prospects. Retrieved 26 June, 2019 from https://www.afdb.org/fileadmin/uploads/afdb/Documents/Publications/2019AEO_2019-EN.pdf

AfDB - African Development Bank. (2011). Enhancing Capacity for Youth Employment in Africa: Some Emerging Lessons. African Development Bank, Africa Capacity Development Brief.

AfDB - African Development Bank. (2015). African economic outlook 2015. African Development Bank, OECD and U.N. Development Program.

Africa Union. (2015). Agenda 2063 - The Africa we want. Framework Document. Retrieved 20 July, 2018 from http://www.un.org/en/africa/osaa/pdf/au/agenda2063 framework-.pdf

Africa Union. (2017). AU Roadmap on Harnessing the Demographic Dividend through Investments in Youth. Retrieved 15 August, 2018 from https://www.africa-youth. org/au-2017-dd-roadmap-final-eng-2

Ahmed, S. A., Cruz, M., Go, D. S., Maliszewska, M., \& Osorio-Rodarte, I. (2014). How Significant is Africa's Demographic Dividend for its Future Growth and Poverty Reduction? Policy Research Working Paper 7134. World Bank Group.

Aidoo, R. (2012). Is Africa the Next Asia? Retrieved 10 May, 2018 from http://thediplomat.com /2012/04/isAfrica-the-next-asia/

ANRC -African Natural Resources Center. (2015). Draft Strategy for 2015 -2020. African Development Bank.

Artadi, E. V., \& Sala-i-Martin, X. (2003). The Economic Tragedy of the XXth Century: Growth in Africa. NBER Working Paper No. 9865.

Aryeetey, E., \& Udry, C. (2000). Saving in Sub-Saharan Africa. CID Working Paper 38, Harvard University, Center for International Development, Cambridge, MA.

Ayittey, G. B. N. (1998). Africa in Chaos. St. Martin's Press.

Baker, D., Delong, J. B., \& Krugman, P. R. (2005). Asset Returns and Economic Growth. Brookings Papers on Economic Activity, 1(1), 289-330. doi:10.1353/eca.2005.0011

Bates, R. H. (1981). Markets and States in Tropical Africa: The Political Basis of Agricultural Policies. University of California Press.

Birdsall, N., Kelley, A. C., \& Sinding, S. W. (Eds.). (2001). Population Matters: Demographic Change, Economic Growth, and Poverty in the Developing World. Oxford University Press. doi:10.1093/0199244073.001.0001

Bloom, D., \& Canning, D. (1999). From Demographic Lift to Economic Lift-off: The Case of Egypt. In Conference Paper for Growth Beyond Stabilization: Prospects for Egypt. Egypt Center for Education Studies.

Bloom, D., \& Williamson, J. (1998). Demographic Transition and Economic Miracles in Emerging Asia. The World Bank Economic Review, 12(3), 419-456. doi:10.1093/wber/12.3.419

Bloom, D. E. (Ed.). (2019). Live Long and Prosper? The Economics of Ageing Populations. A VoxEU.org eBook. Center for Economic Policy Research. CEPR.

Bloom, D. E. (2020). Demographics can be a potent driver of the pace and process of economic development. Finance \& Development, 57(1). Retrieved April 19, 2020, from https://www.imf.org/external/pubs/ft/ fandd/2020/03/pdf/changing-demographic-and-economic-growth-bloom.pdf

Bloom, D. E., \& Canning, D. (2001). Cumulative Causality, Economic Growth, and the Demographic Transition. In N. Birdsall, A. Kelley, \& S. Sinding (Eds.), Population Matters: Demographic Change, Economic Growth, and Poverty in the Developing World (pp. 165-200). Oxford University Press. doi:10.1093/0199244073.003.0007

Bloom, D. E., \& Canning, D. (2011). Demographics and Development Policy. Development Outreach, 13(1), 77-81. 13_1_7710.1596/1020-797X_

Bloom, D. E., Canning, D., \& G nther, F. (2010). Implications of Population Ageing for Economic Growth. Oxford Review of Economic Policy, 26(4), 583-612. doi:10.1093/oxrep/grq038 
Bloom, D. E., Canning, D., Mansfield, R. K., \& Moore, M. (2007). Demographic Change, Social Security Systems, and Savings. Journal of Monetary Economics, 54(1), 92-114. doi:10.1016/j.jmoneco.2006.12.004 PMID:19865594

Bloom, D. E., Canning, D., \& Sevilla, J. (2001). Economic Growth and the Demographic Transition. NBER Working Paper Series Number 8685.

Bloom, D. E., Canning, D., \& Sevilla, J. (2002). The Demographic dividend: A New Perspective on the Economic Consequences of Population Change. Santa Monica, CA: RAND, MR - 1274.

Bloom, D. E., \& Freeman, R. (1998). Economic Development and the Timing and Components of Population Growth. Journal of Policy Modeling, 1, 57-82.

Caldwell, J. (2006). Demographic Transition Theory. Springer.

Canning, D., Raja, S., \& Yazbeck, A. S. (2015). Africa's Demographic Transition: Dividend or Disaster? World Bank Group. Retrieved 26 April 2018 from Error! Hyperlink reference not valid.

Cassen, R. (Ed.). (1994). Population and Development: Old Debates, New Conclusions. Transition Publishers.

Chan, J. (2015). Is China Creating a Workforce with no Soft Skills? British Council. Retrieved 29 June, 2018 from https://www.britishcouncil.org/voices-magazine/china-creating-work

Chidi, O. C., Badejo, A. E., \& Ogunyomi, P. O. (2011). Collective Bargaining Dynamics in the Upstream Oil and Gas Industry: The Nigerian Experience. Proceedings from the 6th African Regional Congress of the International Labour and Employment Relations Association.

Cho, Y., \& Tien, B. (2013). Compilation of 32 SSA Countries. Background Paper for this book. World Bank.

CIA- Central Intelligence Agency. (2017). Natural Gas - Proven Reserves. World Factbook. Retrieved 13 February, 2018 from https://www.cia.gov/library/ publications/the-world-factbook/rankorder/2253rank.html

Coale, A. J., \& Hoover, E. M. (1958). Population Growth and Economic Development in Low Income Countries. Princeton University Press.

Crawford, R., Cribb, J., Emmerson, C., \& Simpson, P. (2020). Retirement Expectations, Attitudes and Saving Behavior: How have these Changed During a Decade of Pension Reforms? Academic Press.

Deaton, A., \& Paxson, C. (1997). The Effects of Economic and Population Growth on National Savings and Inequality. Demography, 34, 97-114.

Deaton, A., \& Paxson, C. (2000). Growth, Demographic Structure, and National Saving in Taiwan. Population and Development Review, 26, 141-173.

Dollar, D. (2016). China's Engagement with Africa: From Resources to Human Resources. John L. Thornton China Center at Brookings. Retrieved 11 August 2018 from https://www.brookings.edu/wp-content/uploads/2016/07/ Chinas-Engagement-with-Africa-David-Dollar-July-2016.pdf

Drummond, P., Thakoor, V., \& Yu, S. (2014). Africa Rising: Harnessing the Demographic Dividend. International Monetary Fund (IMF) Working Paper. WP/14/143. Retrieved from: https://www.imf.org/external/pubs/ft/ wp/2014/wp14143.pdf

Duffy, J., \& Li, Y. (2018). Lifecycle Consumption Under Different Income Profiles: Evidence and Theory. UC Irvine School of Social Sciences. Retrieved 20 April 20, 2020 from https://www.socsci.uci.edu/-duffy/papers/ lifecycle.pdf

Dupriez, O. (2003). Adapting Education to the Global Economy. ERD Policy Brief. Asian Development Bank.

Easterly \& Levine. (1997). Africa's Growth Tragedy: Policies and Ethnic Divisions. Quarterly Journal of Economics, 112(4), 1203-1250.

Eastwood, R., \& Lipton, M. (2012). The Demographic Dividend: Retrospect and Prospect. Economic Affairs, 32(1), 26-30.

ECA - Economic Commission for Africa. (2016). Greening Africa's Industrialization. Economic Report on Africa by the Economic Commission for Africa. United Nations. 
Eloundou-Enyegue, P. M., \& Giroux, S. (2012). Fertility Transitions and Schooling: From Micro-Level to Macro-Level Associations. Demography, 49(4), 1407-1432.

Feeney, G., \& Mason, A. (2001). Population East Asia. In A. Mason (Ed.), Population Change and Economic Development in East Asia: Challenges Met, Opportunities Seized. Stanford University Press.

Fourie, E. (2011, September 28). Africa looks to learn from East Asia's development experiences | Elsje Fourie. Retrieved 29 May, 2018 from http://www.theguardian.com/global-development/poverty-matters/2011/sep/2.

Gonzalez-Garcia, J., Hitaj, E., Mlachila, M., Viseth, A., \& Yenice, M. (2016). Sub-Saharan African Migration: Patterns and Spillovers. Spillover Force. International Monetary Fund (IMF).

Gribble, J. N., \& Bremner, J. (2012). Achieving a Demographic Dividend. Population Bulletin, 67(2).

Hague, N. U. (2006). Beyond Planning and Mercantilism: An Evaluation of Pakistan's Growth Strategy. Inaugural Lecture. Islamabad: Pakistan Institute of Development Economics.

Haq \& Haq. (1998). Human Development in South Asia. Karachi: Oxford University Press.

Herrold, P., Jayawickrama, M., \& Bhattasali, D. (1996). Practical Lesson for Africa from East Asia in Industrial and Trade Policies. The World Bank. Retrieved 16 February 2018 from http://elibrary. worldbank.org/doi/ book/10.1596/0-8213-3484-0

Hooks, G., Makaryan, S., Almeida, P., Brown, D., Cohn, S., Curran, S., \& Moghadam, V. (Eds.). (2016). The Sociology of Development Handbook. University of California Press. Retrieved 1 June 2018 from http://www. jstor. org/stable/10.1525/j.ctv1xxwbg

ILO. (2019). World Employment Social Outlook. International Labor Office. ILO.

IMF. (2019b). Macroeconomics of Aging and Policy Implications. International Monetary Fund (IMF). Retrieved 21 April 2020 from https://www.imf.org/external/np/g20/pdf/2019/060519.pdf

IMF -International Monetary Fund. (2015). Africa Economic Outlook. Washington, DC: IMF.

International Monetary Fund (IMF). (2019a). World economic outlook: Growth Slowdown, Precarious Recovery. IMF.

Johnston, L. (2018). Harvesting from "Poor Old" China to Harness "Poor Young” Africa's Demographic. Africa Bridges Africa, 7(5).

Johnston Lauren A (2016). Africa, and China's One Belt, One Road initiative: Why now and what next? China Bridges Africa, 5(7).

Jong-WHA, L. (2019). Lessons of East Asia's Human Capital Development. Project Syndicate. Retrieved 30 May, 2019 from https://www.project.syndicate.org/commentary/human-capital-east-asia-development-strategyeducation-by-lee-jong-wha-2019-01?barrier=accesspaylog

Jonker, K., \& Robinson, B. (2018). China's Impact on the African Renaissance: The Baobab Grows. Palgrave Macmillan.

Kelley, A. (2001). The Population Debate in Historical Perspective: Revisionism Revised. In N. Birdsall, A. C. Kelley, \& S. W. Sinding (Eds.), Population Matters: Demographic Change, Economic Growth, and Poverty in Developing World (pp. 24-54). Oxford University Press.

Kelley, A., \& Schmidt, R. (1995). Aggregate Population and Economic Growth Correlations: The Role of the Components of Demographic Change. Demography, 32, 543-555.

Kwon, T. H. (2001). The National Family Planning Program and Fertility Transition in Korea. In A. Mason (Ed.), Population Policies and Programs in East Asia. East-West Center. Population and Health Series.

Lee, D. R., \& Reher, D. S. (2011). Demographic Transition and Its Consequences. A Supplement to Vol. 37. Population and Development Review. Retrieved 19 April 2020 from https.popcouncil.org/uploads/pdfs/2011_ PDRSupp_DemTranConseq.pdf

Lee, R., \& Mason, A. (2006). What is the Demographic Dividend? Finance \& Development, 43(3), 1-5. 
Lee, R., Mason, A., \& Miller, T. (2000). Life Cycle Saving and Demographic Transition: The Case of Taiwan. Population and Demographic Review, 26(Supplement), 194-222.

Leff NH (1969). Dependency Rates and Savings Rates. The American Economic Review, 59(5), 886-896.

Linden, E. (2017). Remember the Population Bomb? It's Still Ticking. New York Times: Sunday Review. Retrieved 20 July, 2018 from https//www.nytimes.com/2017/06/15/opinion/Sunday/remember-the-populationbomb-its-still-ticking.html

Lutz, W., Cuaresma, J.C., Kebede, E., Prskawetz, A., Sanderson, W.C., \& Striessnig, E. (2019). Education rather than age structure brings demographic dividend. Academic Press.

Maddison, A. (1995). Explaining the Economic Performance of Nations: Essays in Time and Space. Elgar.

Malthus, R. (1798). An Essay on the Principle of Population. Penguin. (Reprinted in 1970)

Mason, A. (2001). Population Change and Economic Development in East Asia: Challenges Met, Opportunities Seized. Stanford University Press.

Mason, A. (2003). Population Change and Economic Development: What have we learned from East Asia Experience? Applied Population and Policy, 1(1), 3-14.

Mason, A. (2005a) Demographic Dividends: The Past, the Present, and the Future. Towards a New Economic Paradigm: Declining Population Growth, Labour Market Transition and Economic Development under Globalization.

Mason, A. (2005b). Demographic Transition and Demographic Dividends in Developed and Developing Countries. United National Expert Group Meeting on Social and Economic Implications of Changing Population Age Structure. Population Division Department of Economic and Social Affairs United Nations Secretariat.

Mason, A., \& Lee, R. (2006). Reform and Support Systems for the Elderly in Developing Countries: Capturing the Second Demographic Bonus. Genus LX, 11, 11-35.

McGregor, K. (2015). Higher Education is Key to Development -World Bank. University World News, 362. Retrieved from https://www.universityworldnews.com/article.php?story=20150409152258799.

Modigliani, F. (1990). Recent Declines in the Savings Rate: A Life-Cycle Perspective. In the Collected Papers of Franco Modigliani. MIT Press.

Morisset, J. (2000). Foreign Direct Investment in Africa: Policies Also Matter. In Background Paper, The World Bank. The World Bank.

Mwenda, A. M. (2012). Africa versus East Asia. Retrieved 26 August 2018 from http://www. independent.co.ug/ the-last-word/the-last-word/5667-africa-ver

NNPC-Nigerian National Petroleum Corporation. (2018). Oil Production. Retrieved 25 July, 2018 from nnpc group.com/NNPCBusiness/UpstreamVentures/OilProduction.aspx

Ogunjimi, J., \& Dauda, O. (2018). Dynamics of Demographic Structure and Economic Growth in Nigeria. Munich Personal RePEc Archive (MPRA). Retrieved 19 April 2020 from https://mpra.ub.uni-muenchen.de/94988/1/ MPRA_94988.pdf

Olamosu, B., \& Wynne, A. (2015). Africa Rising? The Economic History of Sub-Saharan Africa. International Socialism. Retrieved 13 May, 2020 from http://isj.org.uk/africa-rising/

Oosthuizen, M. (2013). South African National Transfer Accounts 2005: Version 1. National Transfer Accounts Project. Retrieved 11 August, 2018 from http://www.ntaccounts.org

Osotimehin, B. (2015). What can Africa learn from East Africa's boom? Retrieved 14 April, 2018 from https:// agenda.weforum.org/2015/01/what-can-africa-learn-from-east-asia

Phang, H. S. (2005). Demographic Dividend and Labour Force Transformation in Asia: The Case of Korea. In United Nations Expert Group Meeting on Special and Economic Implications of Changing Population Age Structures. Population Division Department of Economic and Social Affairs. 
Premium Times. (2018). 2017 Budget: Again, Nigeria fails to meet UN benchmark on education. Retrieved 15 June, 2018 from https://www.premiumtimesng.com/news/top-news/218097-2017-budget-nigeria-fails-meetun-benchmark-education.html.

Presbitero, A. (2013). East Asia and Africa Growth Experience: Why Divergence? Retrieved 16 March, 2018 from http://utenti.dea.univpm.it/presbitero/Sviluppo/EA-SSA.pdf

Reed, H. E., \& Mberu, B. U. (2014). Capitalizing on Nigeria's Demographic Dividend: Reaping the Benefits and Diminishing the Burdens. Published in final edited form as. Etude de la Population Africaine, 27(2), 319-330.

Reuters. (2014). Ethiopia says expanding zones to become industrial hub. Retrieved February 15, 2018 from https://www.reuters.com/article/us-ethiopia-industry/ethiopia-saysexpanding-zones-to-become-industrial-hubidUSKBNOF91DF20140704

Ritchie, H., \& Roser, M. (2019). Age Structure. World Bank Data. Retrieved 19 April 2020 from https:// ourworldindata.org/age-structure

Robinson, W. S. (1950). Ecological Correlations and the Behavior of Individuals. American Sociological Review, 15(3), 351-357.

Ross, J. (2004). Understanding the Demographic Dividend. Policy Project, 1-8, Retrieved 20 April 2020 from http://www.policyproject.com/pubs/generalreport/DemoDiv.pdf

Rostow, W. (1960). The Stages of Economic Growth: A Non-Communist Manifesto. Cambridge University Press.

Sachs, J. (2002). Rapid Population Growth Saps Development. Science, 297, 341.

Sachs, J., \& Warner, A. (1995). Natural Resources Abundance and Economic Growth. Papers 517a. Harvard Institute for International Development.

Samman, E., \& Watkins, K. (2017). Africa's Opportunity: Reaping the Early Harvest of the Demographic Transition and Ensuring no One is Left Behind. Overseas Development Institute Report. Retrieved 22 April, 2018 from https://www.odi.org/sites/odi.org.uk/files/resource-documents/11812.pdf

Sánchez-Romero, M., Abio, G., Patxot, C., \& Souto, G. (2017). Contribution of Demography to Economic Growth. SERIEs, 9, 27-64. Retrieved 19 April 2020 from https://links.springer.com/content/pdf/10.1007/ s13209-017-0164-y.pdf

Schultz, T. P. (2004). Demographic Determinants of Savings: Estimating and Interpreting the Aggregate Association in Asia. Working Paper 901, Yale University, Economic Growth Center, New Haven, CT. Retrieved January 10, 2018 from http://www.econstor.eu/bandle/10419/20778.

Ssewamala, F. M. (2015). Optimizing the 'Demographic Dividend' in young developing countries: The Role of Contractual Savings and Insurance for Financing Education. International Journal of Social Welfare, 24(3), 248-262.

Statista. (2020). Global Population 1950-2020, by Continent. Retrieved May 15, 2020 from https://www.statista. com/statistics/997040/world-population-by-continent-1950-2020/

Uddin, G. A., Alam, K., \& Gow, J. (2016). Population Age Structure and Savings Rate Impacts on Economic Growth: Evidence from Australia. Economic Analysis and Policy, 52, 23-33.

UNDESA-United Nations, Department of Economic and Social Affairs, Population Division. (2017). Support Ratios and Demographic Dividends: Estimates for the World. Technical Paper. No. 2017/1.

UNDESA-United Nations, Department of Economic and Social Affairs, Population Division. (2017). World Population Prospects: Key Findings and Advance Tables. Retrieved 3 January, 2018 from https://esa.un.org/ unpd/wpp/publication/files/wpp2017_key findings.pdf.

UNDESA -United Nations, Department of Economic and Social Affairs, Population Division. (2015). World Population Prospects: The 2015 Revision. New York: United Nations.

UNESCO. (2012). EFA global Monitoring Report. Youth and Skills: Putting Education to Work. Paris: United Nations Educational, Scientific and Cultural Organization (UNESCO). 
UNESCO. (2017). International Literacy Day 2017. UNESCO Institute for Statistics. Retrieved 13 April, 2018 from uis.unesco.org/en/news/international-literacy-day-2017

UNICEF. (2017). Prioritizing Investment in Children to Reap the Demographic Dividend. Generation 2030. Africa 2.0. Retrieved 26 March, 2018 from https://data.unicef.org/wp-content/uploads/2017/10/Generation_2030_ Africa_2.0_Executive Summary_25Oct17_English.pdf

United Nation. (2007). Development Implications of Changing Age Structure in World Population Focus. As Commission on Population and Development: Opens Headquarters Session. Retrieved 31 August, 2018 from www.webwire.com/ViewPress $=31986$

United Nation. (2012). World Population Prospects: The 2012 Revision. Population Division of the Department of Economic and Social Affairs of the United Nations Secretariat.

United Nations. (2009). World Urbanization Prospects: The 2009 Revision. Population Division of the Department of Economic and Social Affairs of the United Nations Secretariat. New York: United Nations. Retrieved 28 December, 2017 from https://esa.un.org/wup2009/unup/index.asp

United Nations. (2013a). World Population Prospect: The 2012 Revision. Accessed from Population Division of the Department of Economic and Social Affairs of the United Nations Secretariat. Retrieved 24 June, 2018 from http://esa.un.org/unpd/wpp/ index.htm

United Nations. (2013b). World Population Prospect: The 2012 Revision: Vol. I. Comprehensive Tables. United Nations, Department of Economic and Social Affairs, Population Division.

United Nations. (2014). World Urbanization Prospects: the 2014 Revision. Accessed from the Population Division of the Department of Economic and Social Affairs of the United Nations Secretariat.

United Nations. (2017). Changing Population Age Structures and Sustainable Development. Department of Economic and Social Affairs Population Division.

United Nations. (2019). World Population Ageing 2019 Highlights. Department of Economic and Social Affairs.

USAID. (2015). Country Development Cooperation Strategy 2015-2020. USAID. Retrieved July 18, 2018 from https://www.usaid.gov/sites/default/files/documents/1860/Nigeria_CDCS_2015-2020.pdf

Verick, S. (2014). Female Labour Force Participation in Developing Countries. ILO and IZA.

Wapner, A. (2017). Downstream Beneficiation Case Study: Nigeria. Columbia Center on Sustainable Investment. CCSI Policy Paper. Retrieved December 29, 2017 from ccsi. columbia.edu/files/2013/10/Nigeria-Case-StudyMay-2017_CCSI-Final-2.pdf

WEF. (2017). We'll Live to 100 - How Can We Afford It? World Economic Forum (WEF). Retrieved 21 April 2020 from www3.weforum.org/docs/WEF_White_Paper_We_Will_Live_to_100.pdf.

WEF. (2019) For the economy to cope with an ageing population, we must identify new solutions - here's how. World Economic Forum (WEF). Retrieved 20 April 2020 from htpps://www.weforum.org/2019/10/ageingeconomics-population-health/

Williamson, J., \& Higgins, M. (2001). The Accumulation and Demography Connection in Eastern and SouthEastern Asia. In Population Change and Economic Development in East Asia: Challenges Met, Opportunities Seized, edited by Andrew Mason (pp. 123-154). Stanford University Press.

Wood, A., \& Berge, K. (1994). Exporting Manufacturers: Trade Policy or Human Resources? IDS Discussion Paper. Sussex: Institute of Development Studies.

World Atlas. (2018). The World's Largest Oil Reserves by Country. Worldatlas. Retrieved 14 September, 2018 from https://www.worldatlas.com/articles/the-world-s-largest-oil-reserves-by-country.html

World Bank. (2002). Building Human Capital in East Asia: What Others Can Learn. Washington, DC: World Bank. Retrieved 11 May, 2019 from https://siteresources.worldbank.org/WBI/Resources/wbi37166.pdf.

World Bank. (2006). The Changing Wealth of Nations: Measuring Sustainable Development in the New Millennium. Washington, DC: Author. 
World Bank. (2015). Africa's Population Boom: Will It Mean Disaster or Economic and Human Development Gains? The World Bank Group. Retrieved 11 July 2018 from www.worldbank.org/en/region/afr/publication/ africas-demographic-transition

World Bank. (2016a). Global Monitoring Report 2015/2016: Development Goals in an Era of Demographic Change. The World Bank.

World Bank. (2016b). World Development Indicators, 2016. Retrieved 25 May, 2018 from https: //data.worldbank. org/data-catalog/world-development-indicators

World Bank. (2017) World Development Indicators 2017. Retrieved 11 February, 2018 from https://data. worldbank.org/data-catalog/world-development-indicators

World Bank. (2018). Human Capital Index. Washington DC: World Bank. Retrieved 1 May, 2019 from https:// datacatalog.worldbank.org/dataset/human-capital-index

World Bank/DFID. (2005). Country Partnership Strategy for the Federal Republic of Nigeria. Author.

Xinhuanet. (2017). UN decries Sub-Saharan Africa's High Levels of illiteracy. Retrieved 18 May, 2018 from www.xinhuanet.com/english/2017-06/14/c_136365869.htm

Yao, Y., \& Wang, M. (2017). Internal Convergence and China's Growth Potential. In China's New Sources of Economic Growth: Human Capital, Innovation and Technical Change, Volume 2. ANU Press.

Yap, M. T. (2001). Population Policies and Program in Singapore. In A. Mason (Ed.), Population Policies and Program in East Asia. East-West Center. Population and Health Series.

Zamfir, L. (2016). Africa Economic Growth: Taking off or Slowing down? In-depth Analysis. European Parliamentary Research Service. Retrieved 30 May, 2018 from www.europarl.europa.eu/RegData/etudes/ IDAN/2016/573891/EPRS_IDA\%282016\%2957389_EN.pdf

\section{ENDNOTES}

1 The views generated by this argument can be categorized into three school of thought. (1) The pessimists: who believe that population growth restricts economic growth. They debated that world with its fixed resources for growing food would not be able to feed the growing population leading to extensive starvation and death. Proponents of this view comprise of Malthus (1798) and Ehrlich (1968). (2) The optimists: who think that population growth can promote economic growth. Kuznets (1967), Simon (1981, 1986), and Boserup (1981) are some who subscribe to this view, as does Srinivasan (1988) who attributes dearth of economic growth more to unsuitable institutions and policies than to speedy population growth. (3) The neorealist: who propose that population growth has no relation with economic growth. They comprise of Kelley and Schmidt (2001) and Bloom and Freeman (1986), propose that controlling for factors like educational attainment, openness to trade and civil institutions, there is little proof accessible that population growth promotes or restricts economic growth.

2 The Guardian (2016). Population growth in Africa: grasping the scale of the challenge. Retrieved March 16, 2019 from: https:/www.theguardian.com/global-development-professionals-network/2016/jan/11/ population-growth-in-africa-grasping-the-scale-of-the-challenge.

3 Maddison. Monitoring the World Economy: 1820-1992.

$4 \quad$ World War II: After the War, The Atlantic, October 11, 2011. Retrieved May 10, 2020 from https//www. theatlantic.com/photo/2011/10/world-war-ii-after-the-war.

$5 \quad$ Nigeria sets new target to raise oil reserves to 40 billion barrels. 13 October, 2020. Retrieved 15 May, 2021 from https://www.spglobal.com/platts/en/market-insights/latest-news/oil/101320-nigeria-sets-newtarget-to-raise-oil-reserves-to-40-billion-barrels.

$6 \quad$ Nigeria, world's 6th largest oil producer, now world's largest petrol importer. The African Exponent. March 3, 2018. Retrieved 2 March, 2019 from https:/www.africanexponent.com/post/8882-nigeria-isnow-worlds-largest-petrol-importer.

ibid.

$8 \quad$ Interview with a Shell staff on Shell employment situation with Nigerians, January 11th, 2018, in Port Harcourt, River State, Nigeria.

9 ibid. 
Fact Check Did UNESCO ever recommend 26 percent budgetary allocation to education? Premium Times. December 9, 2017. Retrieved 6 June, 2019 from https://www.premiumtimesng.com/news/ headlines/251927-fact-check-unesco-ever recommend-26-per-cent-budgetary-allocation-education.html. The Guardian (2016). Population growth in Africa: grasping the scale of the challenge. Retrieved 18 April, 2019 from: https://www.theguardian.com/global-development-professionals-network/2016/jan/11/ population-growth-in-africa-grasping-the-scale-of-the-challenge. Ethiopia -The Largest economy in East and Central Africa. Ethiopia agrofood. Retrieved on 2 December, 2019 from https://www.agrofood-ethiopia.com/ethiopia-themarket.html Andrew Mason, "Demographic Transition and Demographic Dividends in Developed and Developing Nations," United Nations Expert Group Meeting on Social and Economic Implications of Changing Population Age Structures (Mexico City, 2005). Andrew Mason and Tomoko Kinugasa, "East Asian Economic Development: Two Demographic Dividends," conference on "Miracles and Mirages in East Asian Economic Development" (Honolulu, 2004). Barro, R., and J.-W. Lee. 2013. A New Data Set of Educational Attainment in the World, 1950-2010. Journal of Development Economics. 104 (September). pp. 184-198; and Barro, R. 1996. Determinants of Economic Growth: A Cross-Country Empirical Study. The NBER Working Paper Series. No. w5698. Cambridge, MA: National Bureau of Economic Research. Since 1991, the annual contribution of human capital to growth in SSA has risen to 0.4 percent (Ndulu et al., 2007). See, for instance, policy statements on this issue by the United Kingdom (DfES, 2004), Australia (DEST, 2003), and Denmark (Ministry of Education, 2004). (check the secondary education main paper for the reference). An interview with Brig. Gen. Saleh Bala (Rtd) in Abuja on 2 March 2019. Demography and the future of higher education. International Higher Education. Retrieved 2 April, 2019 from https://ejournals.bc.edu/ojs/index.php/ihe/article/viewFile/7959/7110. 